Article

\title{
Activity-Based Standard Costing Product-Mix Decision in the Future Digital Era: Green Recycling Steel-Scrap Material for Steel Industry
}

\author{
Wen-Hsien Tsai *, Shu-Hui Lan and Cheng-Tsu Huang \\ Department of Business Administration, National Central University, Jhongli, Taoyuan 32001, Taiwan; \\ lanshjoy@gmail.com (S.-H.L.); chengtsu.huang@gmail.com (C.-T.H.) \\ * Correspondence: whtsai@mgt.ncu.edu.tw; Tel.: +886-3-426-7247; Fax: +886-3-422-2891
}

Received: 21 December 2018; Accepted: 5 February 2019; Published: 10 February 2019

\begin{abstract}
According to the advanced technologies of digitalization and automation, the interconnection with each individual object is created from data acquisitions into data feedback in the integrated platform of the Manufacturing Execution System (MES). MES automatically and immediately links various functional systems. The time of electronic production management is coming soon, and Activity-Based Standard Costing (ABSC) will be used in the new era. On the other hand, there are environmental protection issues; thus, the high-tech method of the Electric Arc Furnace (EAF) uses the complicated recycling material of steel-scrap, which hypothetically enhances product-mix decisions, as based on the ABSC theory, with a mathematical programming approach.
\end{abstract}

Keywords: Activity-Based Standard Costing (ABSC); Manufacturing Execution System (MES); Activity-Based Costing (ABC); Enterprise Resource Planning (ERP)

\section{Introduction}

This study integrates two important issues that have received a lot of attention. One attempts to create the Activity-Based Standard Costing (ABSC) theory for the future Digital Era, which follows the simultaneously automatic technology of Data Acquisition in the Manufacturing Execution System (MES) [1-3]. The other is the environmental protection issue of steel manufacturing [4], as conducted in a steel factory case, which adapts the complicated recycling of steel-scrap material $[4,5]$ and further examines more value-enhancing measures regarding the quantity of the output and profit produced during the production processes of steel products. Furthermore, we design the various operating resource parameters of the steel company-related data, which includes the diversified information of a public steel company report, an interview with a top steel manager, seminars, government agencies, etc., in order to fulfill the ABSC product-mix decision goals of a steel factory case.

Traditionally, the Activity-Based Costing (ABC) development was from Cooper and Kaplan (1988) for creating accurate cost management in the accounting field. $\mathrm{ABC}$ has been applied to various industries and used in efficiency improvement, set-up time reduction, performance measurement, product-mix analysis, and budgeting $[3,6]$. The $\mathrm{ABC}$ theory is applied to activity analyses related to factory, company, product, and customer levels $[3,7,8]$ by using the various levels of activities, including unit-, batch-, product-, and facility-level activities $[7,8]$. The ABC model uses two stages in cost assignment: (1) to assign resource costs to activities using various resource drivers and (2) to assign activity costs to various cost objects (parts, products, channels, districts, etc.) using various resource drivers. [3,6,7]. However, while the $\mathrm{ABC}$ method has been used in the Enterprise Resource Planning (ERP) system for a long time, in the Industry 4.0 environment, there is a huge gap regarding how to deal with ABC [9-11]. Some researchers have used the five CPS (Cyber-Physical system) 
attributes of connection, conversion, cyber, cognition, and configuration to further develop industry 4.0 digital environments $[1,12,13]$. Additionally, Internet of Things (IoT) technology network smart objects, the internet, and mobile devices $[1,9,12]$ can be automated for real-time data acquisition $[1,9,14]$. In other words, the data of resource drivers and activity drivers consumed by products during all manufacturing processes can be recorded in real-time using the technologies of sensor-monitoring, the Internet of Things (IoT), CPS, and Manufacturing Execution Systems (MES) under Industry $4.0[1,9,15]$. Therefore, Activity-Based Standard Costing (ABSC) is the future trend in cost accounting under the smart ERP and links the modern MES of Industry $4.0[10,15]$. Practically, the standards of material, labor, and manufacturing overhead data should be installed into the MES database using the advanced technologies of digitalization before starting production $[1,16,17]$. All resources used in all manufacturing processes should be tracked, and their real-time status data should be displayed in the MES system [1,18]. The above technologies and approaches can integrate all activity data to automatically manage and control production processes in real-time and measure operating performance in all operating departments in a digital manner $[1,19,20]$.

Indeed, the functions of MES, including data acquisition and information systems, make production management computerization possible in the digital age [1,2,9]. An MES can automatically communicate with all subsystems of the enterprise operations management-related applications through a workshop, including resource management, interface management, information management, personnel management, quality management, data acquisition, data processing, and performance analysis $[1,10,14]$. Certainly, MES can easily integrate all production management subsystems into its system from data acquisition to data collection, calculation, and storage, as well as data analysis and data application $[2,16,20]$. However, creating a powerful MES platform in a manufacturing factory must consider the different industry production models for various industries, such as continuous or process manufacturing, batch manufacturing, lot-oriented continuous manufacturing, or item-oriented manufacturing $[2,3,7]$. The data acquisition order in any production line is from resource input, to work-in-process (WIP), to finish goods, and then, the data is tracked, collected, and stored in a timely manner $[1,18,20]$. Its advantage is the strict control of all the operating processes to execute the standard procedures of each process, which shows real-time reporting, including various management reports and analysis. All data can be stored in the MES system, which can be used to control all operating activities for the incoming order, from production planning, machining process, assembly process, quality process, and logistic process $[1,2,9]$. Importantly, MES plays an integrating role that links various individual function systems for data collection, combination, and evaluation, which will synchronize to perform related tasks regarding interfacing about orders, materials, machines, tools, and the latest status information of personnel $[1,10,15]$. Smartly, when the production process cannot be run according to the original plan, all information is automatically pooled and appropriately prepared to facilitate good decisions $[1,16,18]$.

In the digital era of global competition, it is noteworthy that MES and ABSC are indivisible and have become more and more important issues. This paper offers an important future development for the study of the relationship between MES and ABSC. There are two main points of view in this business strategy. First, in the market-based view, smart business models should be optimized to communicate with customers, products, and services $[9,18,20]$. Second, in the resource-based view, the integration of resources, capabilities, and processes can create smart business strategic decision capabilities. As all future manufacturing resources can automatically connect and share information, factories will become more intelligent and consciously predict and maintain production lines by autonomously controlling and managing the machines $[1,9,18]$. Furthermore, the Smart Business Model (SBM) will connect its smart products already sold to customers to monitor product components and provide customers with more services [17-19].

Regarding another issue of environmental protection, the Paris Agreement is an agreement within "the United Nations Framework Convention on Climate Change (UNFCCC)", which is for mitigating gas emissions around the world. The 195 UNFCCC members signed the agreement in August 2017 [21]. 
How to protect the environment has become a very important global issue. This paper introduces the literature on steelmaking production by using the complex recycled material of steel-scrap, which largely replaces the global natural resources of iron ore and coal [5,22].

The traditional steelmaking process of a Blast Furnace (BF) has caused serious air pollution and water pollution due to the use of the raw materials of iron ore and coking coal $[4,5,22]$. The manufacturing process of a BF not only causes severe decay of the natural global resources of iron ore and coke but also causes the huge problems of global environmental pollution and gas emission. Fortunately, the development of the modern green manufacturing technology of the Electric Arc Furnace (EAF) replaces the traditional high polluting manufacturing process of a BF; moreover, the recycled raw material of steel-scrap substitutes the natural raw materials of iron ore and coal $[4,5,22]$. An impressive $97 \%$ of all global steel product waste can be recycled to achieve an $86 \%$ recovery rate [5,22]. As EAF manufacturing technology can use any kind of steel-scrap as its material and remanufacture any new steel product, steel-scrap has become the greenest material of the steel industry. The transformation of modern EAF steelmaking technology and traditional raw materials replaces the processes of mining, ore dressing, coking, and ironmaking to save our natural resources and energy; thus, the steelmaking industry will truly become a natural eco-industry $[4,5,22]$.

In this paper, the first major contribution is to propose a concept of ABSC (Activity-Based Standard Costing) integrated into ERP and MES for achieving efficient production management in a digital environment. Smart ABSC analysis and operations will support smart manufacturing, including work forecasting, status monitoring, WIP tracking, throughput tracking, and capacity feedback for all objects because various standard data (including Material Master and Master Data) are installed into the related objects prior to the production process. Smartly, each object can automatically display its information and then share its information with the related requesters in a timely manner through the smart MES platform and the smart subsystem of ERP.

The second major contribution of this study is for environmental protection. The rubbish of steel-scrap has become a raw material for producing steel billets $\left(\mathrm{P}_{1}\right)$ because of EAF technology. Next, the steel billets $\left(\mathrm{PH}_{1}\right)$ produce various new steel products, which certainly help to improve environmental protection. Moreover, enhancing the value of recycled steel-scrap and improving its quality can produce more steel billet $\left(\mathrm{P}_{1}\right)$ outputs in its process. On the other hand, reusing iron ore and coking coal can significantly reduce mining.

The remainder of this paper is as follows: Section 2 presents the research background including (1) the evolution of cost management from the traditional ABC to the innovative ABSC, (2) how to integrate functional subsystems into an MES system for immediate and automatic data acquisition in the system, and (3) a description of the green steelmaking industry. Section 3 creates the ABSC concept by combining the basic theory of $\mathrm{ABC}$ and the standards for the resources and activities of MES. Further, it defines ABSC and describes how to automatically calculate the costs of various cost objects by using the two stages of $\mathrm{ABC}$, where related data can be immediately used for various managerial tasks and decisions, and finally, can build "a powerful MES integrating system". Section 4 describes an ABSC mixed decision model by using mathematical programming for the steelmaking manufacturing industry. Section 5 discusses an illustrative case study. Finally, a numerical example is provided to illustrate how to use the model to obtain an optimal solution using LINGO software. In Section 6 , a scenario analysis of four cases is used to demonstrate the profit analysis $[7,8,23]$ to achieve the maximum profit for steelmaking production. Finally, the summary and conclusions are presented in Section 7.

\section{Research Background}

The era of global high-tech digital is coming. MES systems can automatically and immediately integrate a large amount of software from specific internal functions to external suppliers and customers $[2,10,18]$. A Smart Network and unified interface technologies create a powerful MES integration system, which automatically connects various independent subsystems via networking 
technology and exchanges data in real-time via interfaces $[1,9,18]$. Moreover, as it can support simple input devices, conduct accurate plausibility checks for erroneous inputs, and has convenient information use $[1,19,20]$, MES can provide a reliable and available system for production management [2,9]. However, the readiness of the ABSC model is necessary for the future digital era.

In this steelmaking case, the development of EAF steelmaking technology and the creation of demand for recycled steel-scrap materials will effectively improve climate change [4,5,22]. This steel company wants to focus on accurately evaluating its relevant production costs, including the costs of the raw steel-scrap material, operating costs, and environmental costs, in order to develop their core competencies.

\subsection{The Evolution from the Traditional $A B C$ to the Innovative $A B S C$}

The traditional ABC was developed around 1988 and has been widely used by most enterprises until now. The accurate cost accounting ability of the $\mathrm{ABC}$ model was highly recognized during the mass production of Industry 2.0 and the automated production era of Industry 3.0 [7-9]. However, the 4th industrial revolution, which began in Germany in 2011 [13-15], has the aim of reducing manpower, shortening product lifecycle between design and production, and making efficient use of all resources $[10,12]$. Industry 4.0 develops towards smart factories, smart products, and smart services in the Internet of Things (IoT) environment $[13,16,17]$. In this paper, the innovative ABSC model, which is based on the traditional ABC theory, will be used in the future industry 4.0. The following presents the technological gaps between $A B C$ and $A B S C$ as well as three key points for the innovative ABSC in the future Industry 4.0 environment.

- CPS: All smart objects can be intelligently connected together and can continuously interchange data in a timely manner [1,24].

- IoT: The IoT is a ubiquitous virtual infrastructure, also called industrial internet $[25,26]$.

- Sensor technology: Smart objects are embedded with various different sensors and can be perceived, observed, and understood through computers without the need to enter data $[10,16,27]$.

On the other hand, the ABC model has been used in the ERP system for a long time. Assuming that the ABSC model will be used in the ERP system, we must consider the issue of system integration. For example: (1) Smart data are embedded in the ERP system and can share all smart data to related smart objects before production $[10,15]$. The system-to-system issue, ERP, and MES system-related data issues are from data acquistion to data feedback $[15,24,27]$.

Finally, the ABC model has been adopted by many industries to improve efficiency [3,6]. From the point of view of business strategy and planning, the ABC/ABSC product-mix decision model can be solved by using the LINGO software to obtain the optimal decision solution to maximize profit, which is helpful to enterprises $[7,8,23]$. In the future Industry 4.0, Big Data and cloud computing can be used to make real-time decisions $[14,28,29]$. In this subsection, we recommend that the ABC/ABSC product-mix decision model can be used to determine the optimal solutions regarding business strategy and enterprise budget $[23,28,29]$ in the Industry 4.0 era. On the other hand, we recommend that the reference LINGO software system be part of the specification for Big Data policy systems.

To sum up, this subsection describes the evolution of cost management from the traditional ABC model to the innovative ABSC model, including the technological developments and the application of ABSC in Industry 4.0, as shown in Table 1. Figure 1 shows a smart ABSC operational roadmap from strategy to planning and execution in the future industry 4.0 Environment.

\subsection{Integrating Functional Subsystems into an MES}

Obviously, a large number of traditionally independent software (such as ERP) can only provide a one-way supply of the related data; however, MES plays a dialogue platform and integrates all independent systems [2,15]. Smartly, various resources are applied to different systems individually, which execute during the production process to manufacture the products $[15,20,30]$. 
Many independent systems are applied and integrated by MES systems [2,9], meaning MES systems can integrate a variety of various independent function systems, and this subsection will introduce some of the functional systems. First, in the production area, MES integrates a Programmable Logic Controller (PLC) system [2,25], which is a digital control system that prevents operational errors and automatically collects all relevant manufacturing information $[1,2,18]$. The Statistical Process Control (SPC) system is a quality management system $[1,10]$ which features rapid reaction to production-line abnormalities and effective dispatch of expert personnel to repair and immediately eliminate mechanical or personnel processing anomalies. In addition, the Shop Floor Control (SFC) system can carry out quantity control and transfer on the production line $[1,2,10]$. Second, in the warehouse area, MES integrates the Warehouse Management System (WMS) for accurate inventory management $[2,15,30]$. Third, in the inventory area, MES can be vertically integrated into the Supply Chain Management (SCM) system [2,10,14] with its suppliers to achieve "Just in time" (JIT) [7] management to reduce inventory. Fourth, in the data area, currently, Enterprise Resource Planning (ERP) provides complete information about a company or group; however, the actual details of manufacturing processes are difficult to provide $[2,15]$. Therefore, a wide variety of individual hardware and software have been developed, and all hardware are distributed in one factory in order to generate their data in a timely and automated manner, which is due to CPS and the IoT technologies [31-34]. MES can immediately receive data from all individual systems and send real-time data to those in demand.

Table 1. Innovative Activity-Based Standard Costing (ABSC) and applications.

\begin{tabular}{|c|c|c|}
\hline $\begin{array}{l}\text { Traditional Activity-Based Costing } \\
\text { (ABC) }\end{array}$ & Technological Development & Innovative ABSC \\
\hline Resources & $\begin{array}{l}\text { 1. Technology environment: Cyber-Physical system (CPS) } \\
\text { and Internet of Things (IoT) } \\
\text { 2. Software and hardware: Integrated Manufacturing } \\
\text { Execution System (MES) and various independent } \\
\text { systems (system-to-system) }\end{array}$ & $\begin{array}{l}\text { Smart resources: } \\
\text { 1. } \quad \text { Resource standards: Smart Data } \\
\text { 2. } \quad \text { Smart resource objects: Advance Robots, } \\
\quad \text { Automatic Machines ... }\end{array}$ \\
\hline Activities & 3. Data acquisition infrastructure (ID reader, & Smart Activities: Smart resource into operation \\
\hline $\begin{array}{l}\text { Products } \\
\text { (Cost Objects) }\end{array}$ & 4. Connection of the automation level (Scale, Bar & Smart Products: \\
\hline $\begin{array}{l}\text { Using system: } \\
\text { Enterprise Resource Planning (ERP) } \\
\text { ERP data, including all standard costs }\end{array}$ & $\begin{array}{l}\text { 5. Smart Data: Standards of Material Master and } \\
\text { Standards of Master Data } \\
\text { Applications: Automated and real-time data acquistion } \\
\rightarrow \text { data feedback Machine-to-Machine (become } \\
\text { conscious and intelligent) }\end{array}$ & $\begin{array}{l}\text { 1. Using system: Smart ERP Smart ERP-data, } \\
\text { including: smart data and their } \\
\text { standard unit-price } \\
\text { 2. A powerful platform: MES system } \\
\text { 3. Smart Data applications/data feedback }\end{array}$ \\
\hline \multicolumn{3}{|c|}{$\begin{array}{l}\text { ABC/ABSC Application: product-mix decision model } \\
\text { Method: various constraints and mathematical programming } \\
\text { Using strategic system: Decision Support System } \\
\text { Results: an optimal decision solution for maximizing profit } \\
\text { ABSC application in the Big Data of Industry } 4.0 \text { : } \\
\text { Recommendations: }\end{array}$} \\
\hline $\begin{array}{l}\text { 1. Strategy: ABSC Product-mix deci } \\
\text { 2. Reference LINGO software syster } \\
\text { 3. Plan: the optimal decision solutio }\end{array}$ & $\begin{array}{l}\text { ion support model as part of Big Data strategy } \\
\mathrm{n} \text { as part of a Big Data strategy system specification } \\
\mathrm{n} \text { as budget target }\end{array}$ & \\
\hline
\end{tabular}




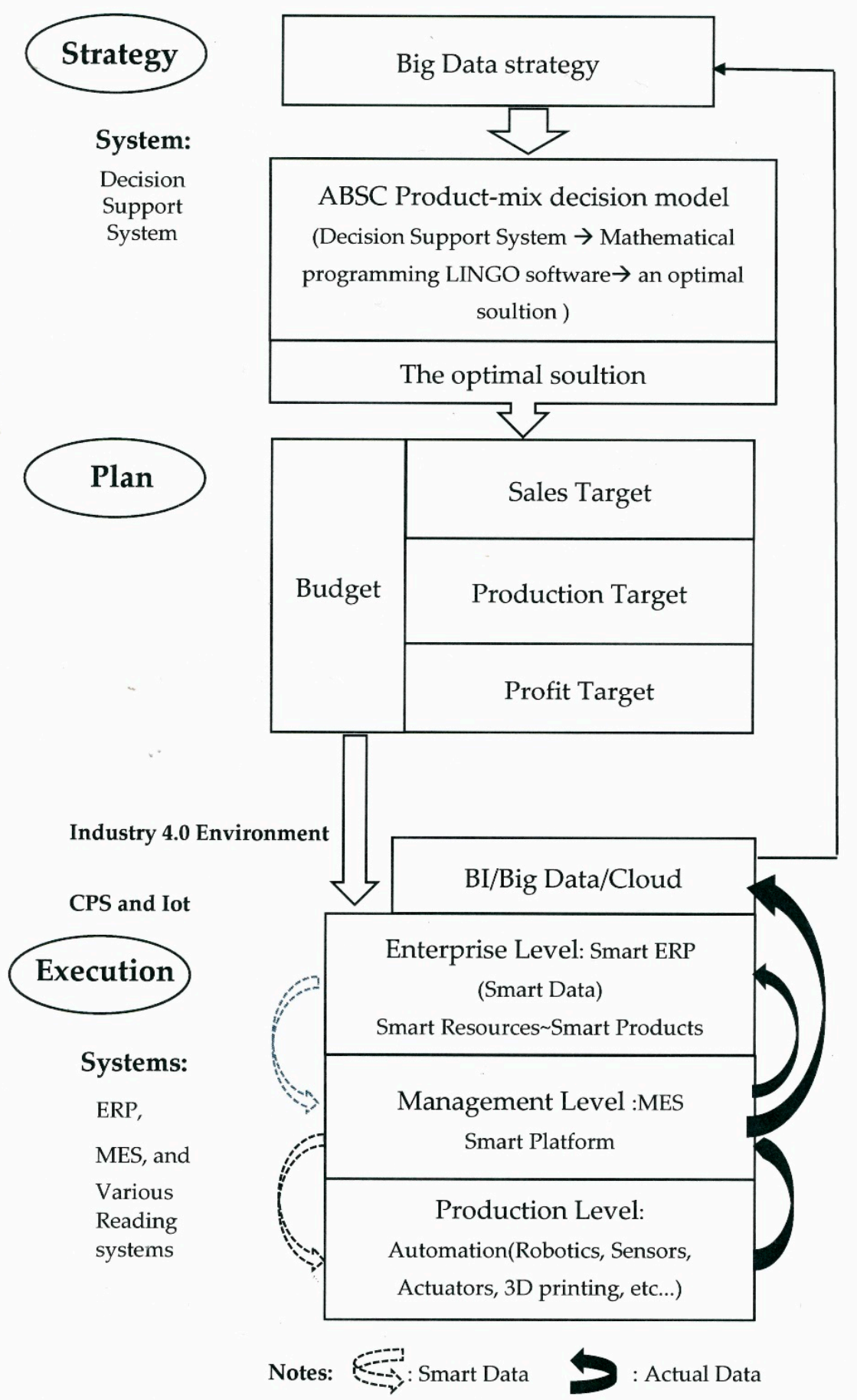

Figure 1. Smart ABSC operational roadmap.

Indeedly, the MES system can solve ERP-related problems and easily collect massive amounts of data during the production process. Finally, in the data application area, the Business Intelligence (BI) system $[2,10,15]$ can be horizontally integrate through an internal database in an ERP system, and all department managers can easily obtain their analysis information if they are authorized access to such related information $[2,15,30]$. It is entirely conceivable that MES can become the backbone of production management; MES integrates a large number of digital products and systems to improve information processing capabilities, which allows it to become a powerful production management system for achieving the goal of intelligent manufacturing [35-37]. 


\subsection{Automatic Data Acquisition in Real-Time in an MES System}

Data acquisition is automatically collected via a variety of reading systems, including counters, scales, balances, and comparable devices [34,37,38]. For example: (1) the technology of an ergonomic touch screen is for conducting data acquisition $[2,10,12,13]$; (2) staff members log their work time using PDA (production data acquisition) [13,28,39], and a cell phone is convenient for conducting immediate mobile data acquisition [2]; (3) RFID (radio frequency identification) [2,18,38] can conduct remote data acquisition [2,9] in the harshest production environments; (4) counter pulse operating signals can automatically and immediately collect the yield data [2]; lastly, (5) using barcodes or batch labels that can be scanned at their storage location is to collect data in real-time $[2,13,15]$. In other words, MES can collect all kinds of data (such as the characteristic curves of quality data, labor time data, wage data, and material data), and all data of the operational processes are stored in the MES database [2].

Remarkably, production process mapping [2] is embedded into the smart MES, which will connect with all the data collection systems via a uniform interface, and all devices will automatically collect messages and perform all data acquisition activities from the start to the final workstation $[1,2,9]$. Thus, all information will be supplied to managers, customers, and suppliers in a timely manner $[9,34,37]$.

\subsection{Background of Steel-Scrap for Green Steelmaking Manufacturing}

The use of modern EAF technology instead of the traditional BF technology and adopting the raw material of steel-scrap to reduce the natural energy excavation of iron ore and coal will save $35 \%$ of the oil manufacturing costs [22]. Furthermore, the modern production processes of EAF can significantly reduce $75 \%$ of carbon emissions [22], as compared to the traditional $\mathrm{BF}$, in order to promote and maintain a healthy global environment.

In the future, the EAF production model will gradually replace the traditional BF manufacturing method in the global steelmaking industry, as steel-scrap raw materials will replace iron ores in large quantities. Every city has a large number of discarded old steel products, which are the source of steel-scrap, including motorcycles, automobiles, rails, furniture, appliances, building demolition, etc. [5]. Steel-scrap will become a secondary mineral due to the large number of recycled old steel products, rendering the steelmaking industry a recycling eco-industry [22]. Through the two concepts of automatic data acquisition and green steelmaking manufacturing, it provides an important development for the ABSC literature in steelmaking manufacturing.

\section{ABSC in ERP Applications and Linking MES}

The ABC model uses a two-stage procedure to calculate product costs: resource drivers and activity drivers. Resource costs are traced to activities using resource drivers, and then, activity costs are traced to cost objects using activity drivers as shown in Figure 2. In the first stage, various resource drivers are used to assign resource costs to the related activities. In the second stage, the activity costs are assigned to the products using the activity drivers. Each activity center usually consists of related activities through a clustering process $[27,30,39]$. Additionally, all elements of each activity cost pool come from different resource costs and can be traced to their related activity center $[23,28,29]$. 


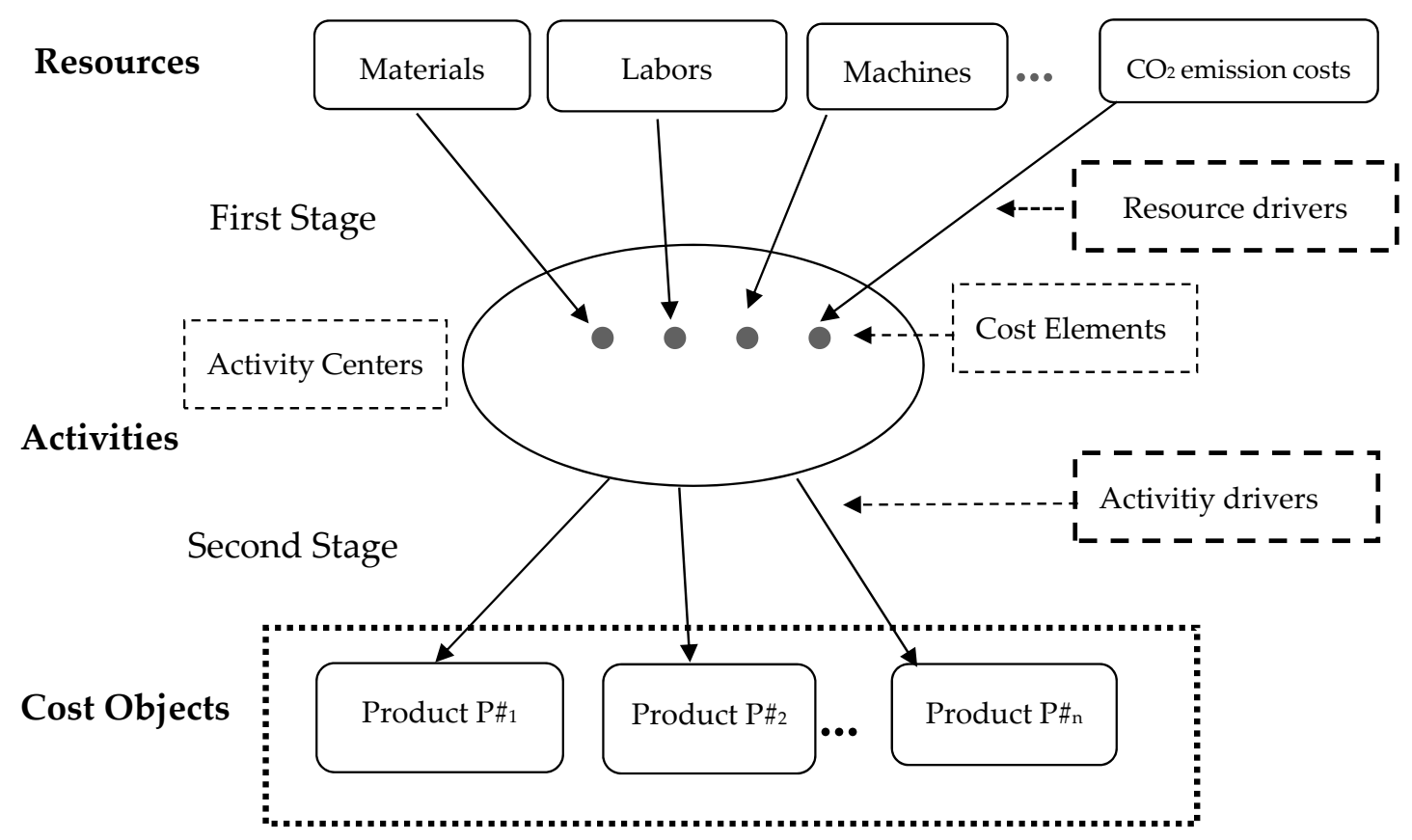

Figure 2. The detailed ABC model.

It is assumed that ABSC (Activity-Based Standard Costing) is embedded in the ERP link with MES, which creates the data storage and information exchange and updates each other every 15 minutes $[2,10,31]$. From the business practice point-of-view, all industry-relevant objects, such as raw materials, products, machines, customers, and supply chain, can connect with each other for exchanging information and controlling actions independently or autonomously $[2,9,15]$. Various resources and activities in the ABSC are embedded in an intelligent ERP $[10,15]$, which is also a subsystem of MES. MES is a powerful platform that automatically connects to all independent systems and immediately delivers accurate costs for each product due to its smart integrated data stream including data acquisition, data collection, data storage, data calculation, and data analysis [12,20,27]. Thus, MES's data application can be applied to customers, channels, or markets in a timely manner to fulfill computerized production management $[11,24]$ in the future digital era.

From the management accounting point-of-view, while the traditional ERP system seems to provide all the information of a company or group, the actual data of the manufacturing process can hardly provide all detailed records in real time, such as working hours; utilization of machines; or equipment, material loss, WIP quantity control, etc. [10,15]; therefore, real-time data acquisition will overcome the above problems $[15,24,35]$. The following describes the standards for the resources and activities in a digital factory.

\subsection{Resource Standards}

Input manufacturing resources include raw materials, machines, tools, laborers, etc. The costs of all resources must be properly assigned to the related operating process using the standards of the Material Master and Master Data lists [9,27,37]. A Material Master list, such as the bill of materials information, includes drawings and required quantities $[2,15,24]$. Another Master Data list is for the work plan, including work instructions, work centers for planned production, set-up time, running time, and standard speed installed to each related machine; all of which are the standards for all production process mapping $[2,15,20]$. For example, the above various resource standards are installed in the related advanced robots or automatic machines, and they are embedded with a variety of sensors to collect all the data from production operations in a timely manner. The process of collecting data is called the data layer for comprehensive perception [10]. 
Additionally, different functional workers, including material controllers, production schedulers, production labors, and logisticians, use the online MES information platform to integrate various independent functional systems $[2,15,39]$ to make preproduction plans. Furthermore, data acquisition from all the input resources are via various reading systems $[2,13,27]$, which automatically receives the information into the data acquisition station $[2,19]$ while simultaneously transferring the information into the MES database [2]. After that, the MES database will feed the data back to all the related independent systems $[2,15,18]$. Data feedback is the data layer of reliable transmission.

According to the above explanation, the various data acquisitions and data processes will follow three steps. First, set the various standards of the Material Master and Master Data, which are embedded in the advanced robots or automatic machines $[2,11,27]$. Second, the data layer of comprehensive perception by various sensors and multi-sensor systems automatically acquires data in a timely manner during the operational process $[2,15,38]$. Lastly, the data layer of reliable transmission collects feedback data and transfers them to the related systems in real-time $[2,10-13,15,16,18,34,35]$. According to the above data acquisitions, they will automatically collect various Big Data and thus can achieve the submission goals of a smart factory $[1,9,24]$.

\subsection{Activity Standards in the Future Production Process}

A powerful MES system automatically connects with various functional systems to successfully conduct production management $[1,2]$. The following introduces the different operational activities.

\subsubsection{The Simulation of Production Strategies}

Smart design management can use 3-D printing to make a perfect design prototype before starting production $[1,2]$. Then, the smart software system will be used to simulate the manufacturing process beforehand [2,24]. MES will make the best plan for production management $[2,31,37]$ by considering how to arrange all the types of intelligent automatic machines within the factory and how to conduct good production operations. For example, it can calculate the consumption of various resources in each production process, such as people, space, energy, materials, equipment, etc [2,19], which can help significantly reduce the operating time. An advanced planning and scheduling (APS) system [2] can be used to make detailed manufacturing plans, including listing all the allocated resources and integrating them into this modern MES system. From the manufacturing process point-of-view, a production line using the MES system can be broken down into the individual machines in each production process to collect the data, including the quantity of raw materials, machine time, tool time, manpower time, etc. [1,2,19]. On the other hand, the quality data achieved from the production processes using the visual mode can achieve the goals of quality management [2].

\subsubsection{Tools}

The technology of Augmented Reality (AR) [13] has made great breakthroughs in production management. For example, for job training, workpeople can wear smart glasses to scan their working sites by creating a smart virtual screen that simulates the working conditions. In other words, Standard Operating Procedures (SOP) can be visualized in a timely manner by using the AR's technology in production process simulations [13]. In this way, we can reduce the cost of training and avoid the loss of production.

\subsubsection{Information Technology for Horizontal and Vertical Integration}

The MES system creates an important internal and external integrated system by connecting various independent horizontal and vertical systems, meaning it can effectively enhance all functions and support all related requests to achieve efficient digital factories $[2,26,27]$.

Horizontal integration means that a company can integrate all of its internal functions and systems, such as engineering, production, and sales service. All data from all departments are automatically entered into their individual system, and the data can be shared with other related departments (each 
15 minutes) by the powerful MES platform [1,2,15]. For example, the data layer of reliable transmission through the MES platform can integrate the data from all departments into the ERP system every 15 minutes $[2,9,15]$. On the other hand, vertical integration is a thinking of an industry chain; it means that a smart company can develop a cooperative information platform for their suppliers and customers to facilitate their timely exchange of related information [26,34,35]. For example, if the machines are broken down, the suppliers can use the platform's data to know when they should support the machines.

\subsubsection{Machine-to-Machine Communication}

The most significant change in the new manufacturing environment is that all auto-machines can send their information to each other in a factory or different factories [10,27]. From a supply chain point of view, the information of all machines is connected together through MES, and the MES data can be linked to a cloud system $[18,26,34]$. In other words, each industry chain data will be connected together, and they can know each other. For example, if our suppliers are out of stock, we can know it through cloud system and MES and make a good decision to resolve our inventory problem. Furthermore, the technologies of cloud and IoT $[18,26,34]$ can also store data for each industry chain and can collect marketing information to make real-time decisions using Big Data and cloud computing $[1,18,32]$.

\subsection{ABSC Application in a Digital Manufacturing}

$A B C$ is widely used in a variety of industries to manage and control businesses $[3,23,28]$, and ABSC can be used to timely analyze the functional costs of its departments [26], such as production, sales, human resource, research and development, information systems, procurement, project management, product design, performance measurement, efficiency improvement, product-mix analysis, set-up time reduction, quality cost measurement, environmental quality management, budgeting, etc. [7,28,29].

In digital factories, all components can indeed be controlled at any time in a powerful MES system: Smart design, smart development, smart manufacturing, and smart selling in a perfect industrial chain system that uses a reliable information technology of horizontal and vertical integration $[18,26,35]$. All components have autonomous perception, independent forecasts, and self-configuration capabilities to make standard productions or service practices for achieving perfect human-machine interaction $[1,2,27]$. These technologies will rapidly improve productivity. On the other hand, setting the various standards of the Material Master and Master Data in all smart systems will easily fulfill a variety of standard costs at the unit, batch, product, and facility levels to achieve the needs of factories, businesses, products, and customers in a timely manner $[1,2,18]$.

In the digital era, a smart infrastructure of data acquisition terminal equipment includes scale interfaces, data interface bus systems [2,24,33], counter pulses operating signal, process values, accompanying document labels and ID reader in the environment of a Cyber-Physical System (CPS), and the Internet of Things (IoT) technologies [1,9,37]. The first automatic data are from the data layer of comprehensive perception, which creates the automatic huge-data from data acquisition and data collection to data storage [2,10]. Then, these huge-data become a useful information media that can share various information to related individual systems or devices, including machine-to-system, system-to-system, or machine-to-machine [1,2,27], which we call the second data layer of reliable transmission. The huge-data can be stored in cloud systems for the needs of customers or suppliers $[1,34,35]$. The cloud systems [26] can also automatically calculate their huge-data and become a variety of smart information for different requesters, which we call the third data layer of intelligent processing.

Specifically, MES plays a backbone role, integrating all the independent horizontal and vertical systems $[2,15,26]$. Importantly, data acquisitions and data processes automatically collect large amounts of data during the production process from input resources and activities to finished products $[2,15,24]$. 
Figure 3 displays the relationship between ABSC and digital factories through smart MES and ERP. Huge-data are entered into the MES data station through a variety of sensors, and then, the data feedback are entered into the ERP database $[1,2,18]$.

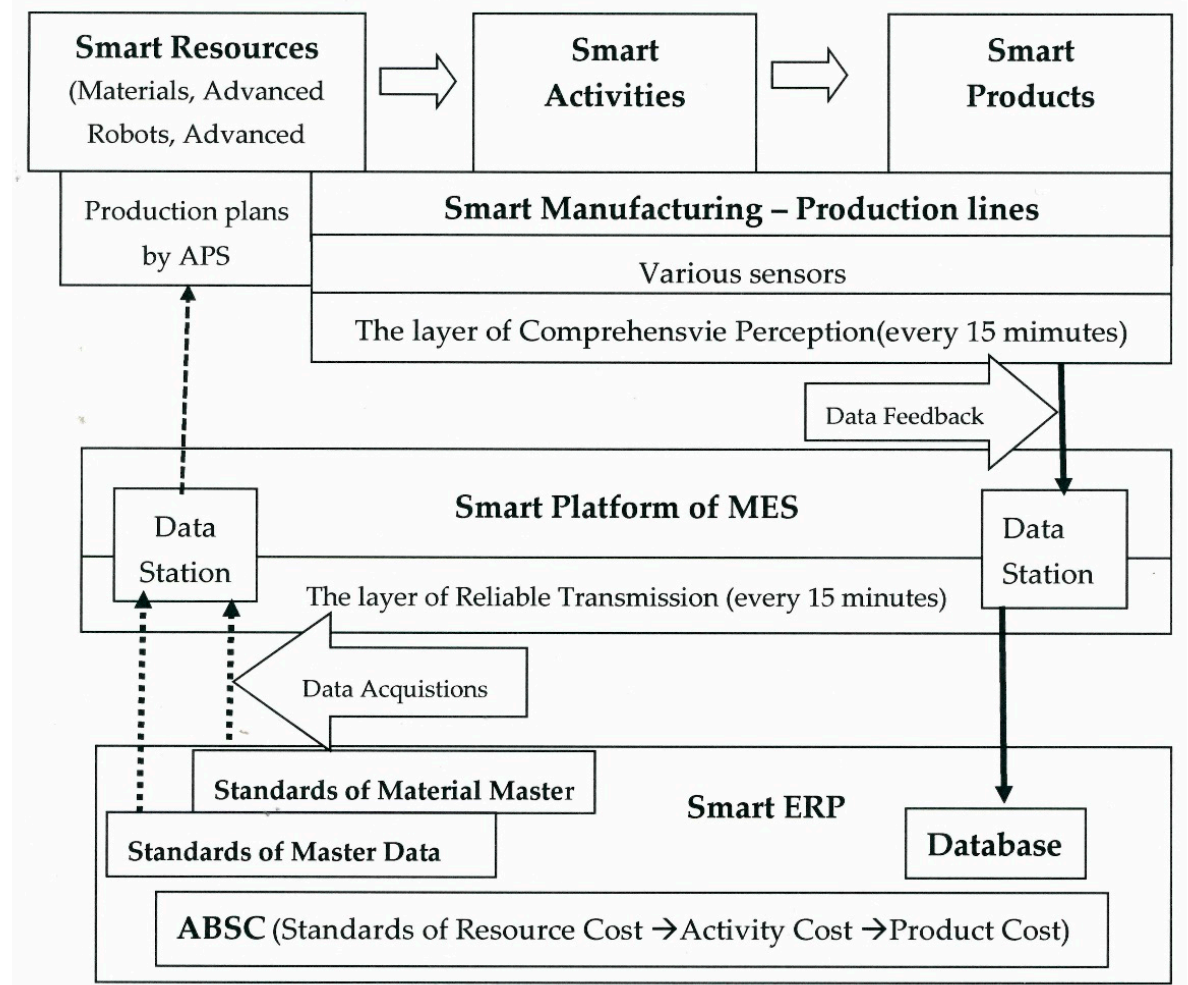

Figure 3. Achievement of ABSC goals through Smart MES and ERP systems.

\subsection{ABSC Definition and Various Cost Calculation}

Cooper and Kaplan (1988) adapted ABC for improving the cost of products in an automated manufacturing environment; however, that is not enough for the individual objects required in the digital age. In an MES system, all resource smart objects $[18,24,27]$ are installed with the related standards of the Material Master and Master Data $[2,10]$ before those objects enter the production process, which we call Activity-Based Standard Costing (ABSC). Those operation-related detailed huge-data are collected by various sensors, and massive amounts of data will automatically be created during the production process, which will facilitate the implementation of ABSC in ERP and MES systems $[1,2,15]$.

According to the previous discussion, ABSC can be embedded in a Smart ERP system and connected to the MES system in a digital factory $[10,15,24]$. The ABSC approach for a steel company can be successfully implemented by following four steps (see Figure 2):

- Step 1. Calculating Resource Costs: The various resources used in a factory may include direct materials, direct laborers, machine hours, and other resources [3,6,28]. Resource costs are calculated using the quantity standards of the Material Master and Master Data [2] in the production process, as well as the standard of each resource unit price $[7,8,28]$. All detailed quantity data throughout the whole operation process can automatically be summed up for each resource element and then be tracked to its processes. As a result, resource costs can be calculated immediately in a smart ERP system.

- Step 2. Tracing Resource Costs to Activities: According to the various automatic data acquisitions in the data processes, some direct resource costs can automatically be traced to specific activities if 
a resource is consumed only by the specific activity $[15,18,27]$. Otherwise, the resource cost should be assigned to activities that consume the resource by an appropriate resource drive $[2,10,27]$.

- Step 3. Standardized Activity Costs: An activity may be related to more than one process; thus, its indirect costs will be distributed to the related processes in the MES system [2,15,23]: For example, inspecting incoming material, moving materials, and indirect labor costs; maintaining and repairing machines; and other costs that are beneficial to all the manufacturing processes [15]. In other words, standardized activity costs can be traced to their related activities and processes $[2,10,15]$, and the cost of each activity can be automatically calculated by adding the costs of the resource elements assigned to the activity $[7,10,15]$. In the new manufacturing era, mass customization is the key focus of manufacturing processes. Traditional standard costing should be changed to setting the detailed standards for elementary cost elements $[2,15,18]$. Thus, we will have the standard cost rate for each activity executed in the productions system. The standard cost of a specific product unit will be calculated by adding the products with standard activity cost rates and standard activity driver quantities consumed by this specific product unit $[15,23,28]$.

- Step 4. Tracing Activity Costs to Products: The product cost for a specific product unit can be automatically calculated by summing up the resource and activity costs traced to a specific product unit $[15,23,28]$.

\subsection{ABSC in ERP and linking MES in A Smart Factory}

To sum up Section 3, the resource standards use the standards of the Material Master and Master Data $[2,15,27]$, which are installed in the related smart objects prior to production. After that, all smart objects will automatically operate their operational activities and acquire their data in a real-time manner $[2,10,15]$. Regarding the software, this powerful MES system not only integrates all automatic and real-time data from all reading systems into the MES database [2,12,24] but also shares the relevant requirement data through the platform $[2,12,24]$. Additionally, the MES system automatically connects the internal and external independent systems for horizontal and vertical integration to achieve the goals of smart factories [2,10,24].

From a cost accounting point-of-view, one should understand a smart factory, including how to connect the ERP and MES; the following steps can be followed. Firstly, the structure of a smart factory has four levels, Production Operation, Production Management, Business Operation, and Commerce, with multiple control systems: MES system, ERP system, and BI system. Secondly, Sections 2 and 3 provide many different MES information, including operation processes, functions, and software, to design a powerful MES integrated system for a smart factory. Finally, in particular, the SAP-ERP system mainly includes the following seven modules in order to display ABSC in the CO module: SD (Sales and Distribution), PP (Production Planning), MM (Materials Management), QM (Quality Management), HCM (Human Capital Management), CO (Controlling), and FI (Financial Accounting) [40]. Figure 4 shows a smart factory can use the MES integrated systems in the future Industry 4.0 era. 


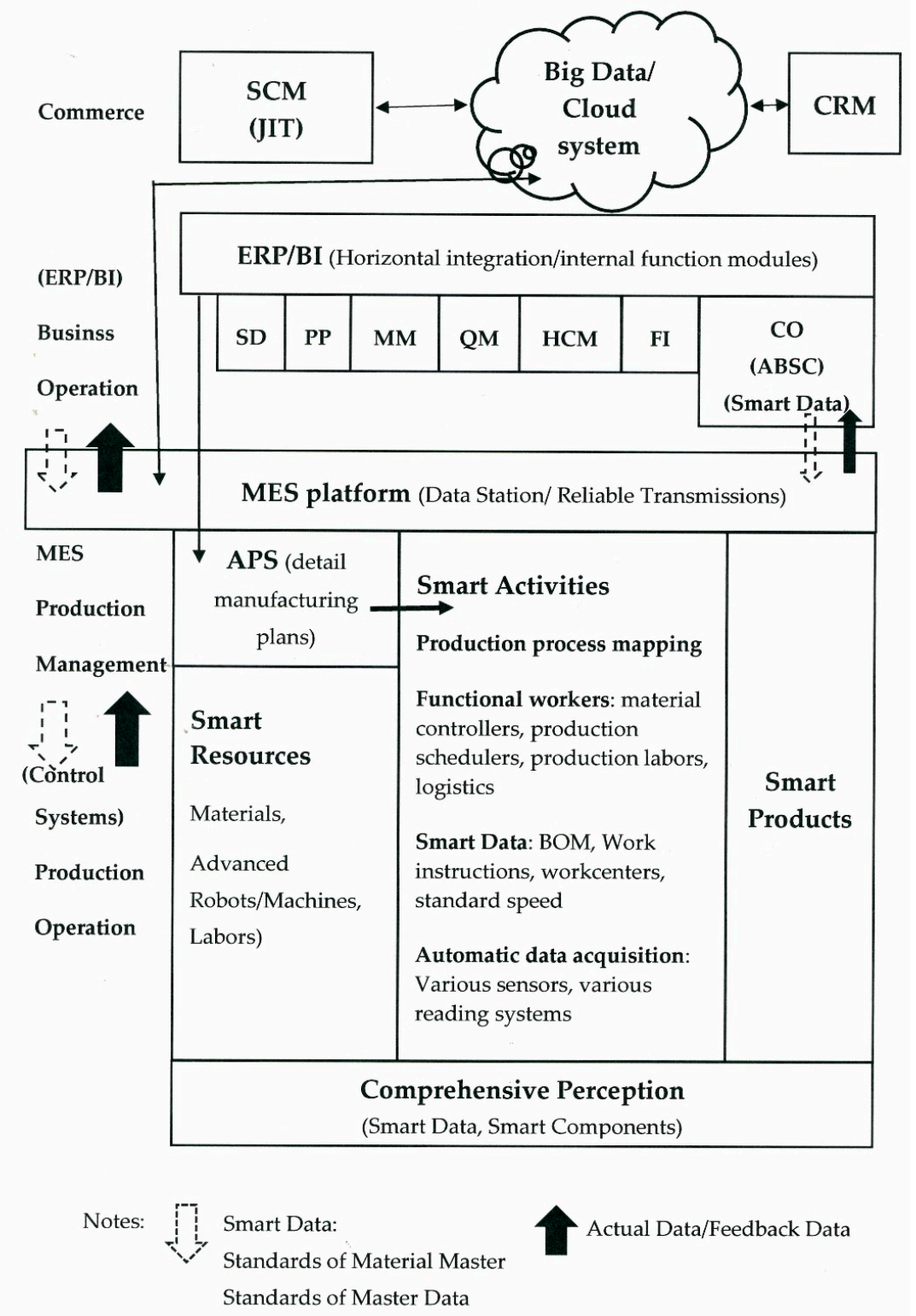

Figure 4. A powerful MES integrated system.

\section{Formulation of an ABSC Product-Mix Decision Model for a Steel Factory}

Jadicke (1961) applied the Product-Mix model in management accounting to determine the optimal product-mix $[23,29]$ that maximizes total profit under various constraints (e.g., sales, production, and cost elements) in a multiproduct company. Additionally, $\mathrm{ABC}$ uses various mathematical programming approaches and conducts a product-mix decision analysis [23,29]. The ABSC theory will be applied in new manufacturing.

\subsection{Process Descriptions and Cost Categories for the ABSC Mixed Decision Model for a Steel Factory}

Bottom line results (e.g., the income statement in the accounting field) are from sales and various costs to profit, which can be used to evaluate the competitiveness of a company [23,29], and such results are absolutely related to the performance of each functional department. All cost information must be shown, in order for business operators to make good assessments and accurate judgments. This study classifies six cost categories as follows: 
1. Material cost: The purchase of steel-scrap raw materials should be based on the needs of EAF to clean, cut, and fracture for finishing all kinds of different sizes. The available steel-scrap will be poured into the hopper of EAF according to size in order for the EAF to be fully loaded and then will start the production of $\mathrm{P \#}_{1}$ products.

2. Labor cost: Including personnel normal and overtime costs;

3. Electrical power cost: Including the high electrical bills for EAF, etc.;

4. $\mathrm{CO}_{2}$ emission cost: Environmental and social costs in the form of a carbon tax for environmental protection;

5. Machine cost: Machines and equipment are fixed costs in each process;

6. Other indirect costs (overhead): With the exception of the above 1-5 costs in this subsection, other indirect costs per product are calculated as a percentage of the total amount sold for each product.

The flowchart in Figure 5 describes the processes in steel manufacturing. This study includes two main stages. On the one hand, we focus on incorporating the above costs (e.g., Material cost, Labor cost, Electrical power cost, $\mathrm{CO} 2$ emission cost, Machine cost, and other indirect costs) through a mathematical programming approach and obtain the optimal decision using the LINGO software. On the other hand, we hypothesize and enhance the value of steel-scrap raw materials for $\mathrm{P \#}_{1}$ products in the process of steelmaking to achieve maximum profit. The flowchart of the steel factory is shown in Figure 5.

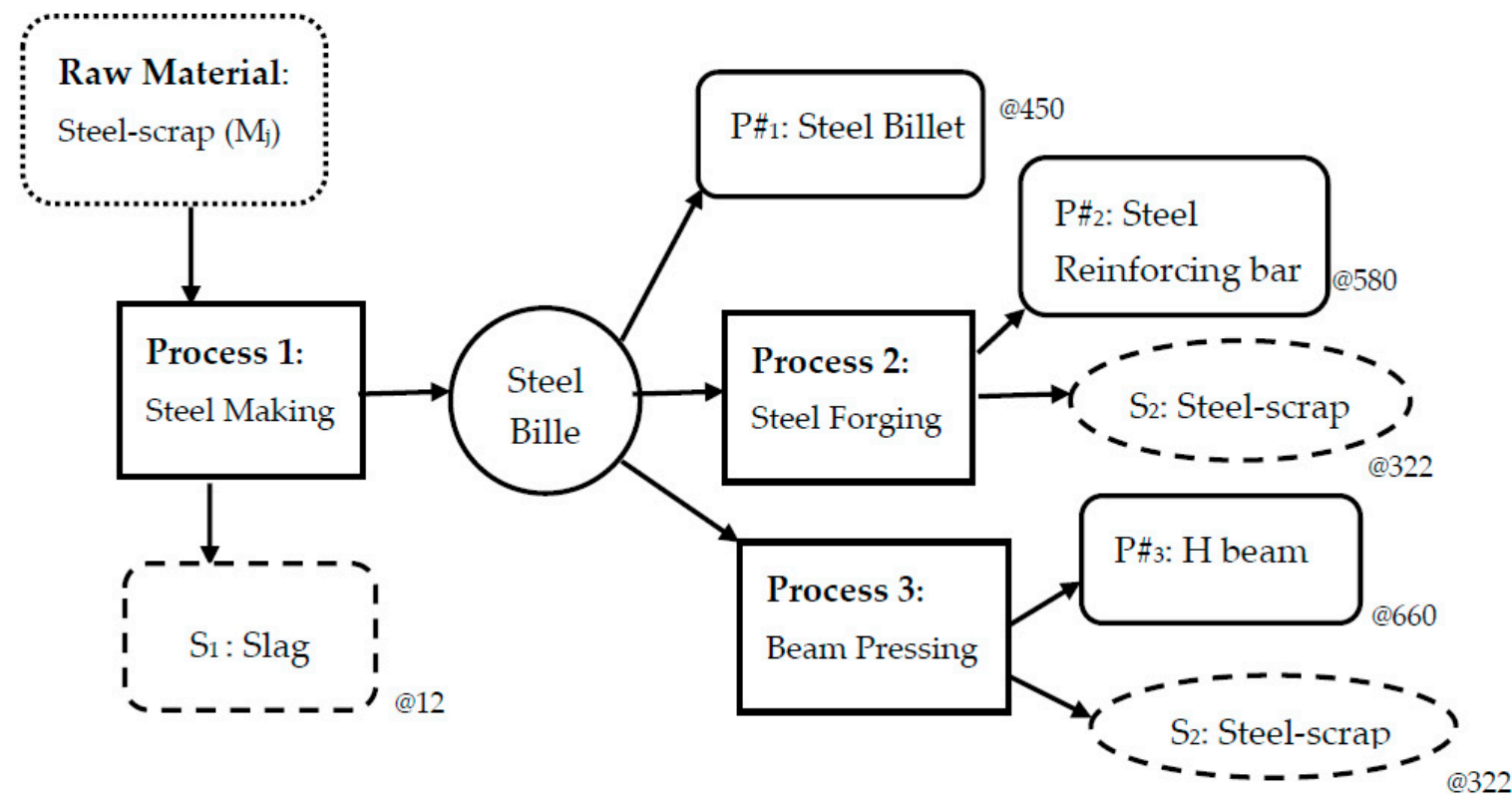

Figure 5. The production process of the steel factory of the case company.

\subsection{Assumptions}

Assuming that the ABSC product-mix decision in a steel factory considers all operating costs in this paper, there are several assumptions. The following assumptions will be incorporated into a mathematical programming model:

1. The revenue includes steel products and slag byproducts;

2. The direct raw material cost of steel-scrap with different purity levels and recycled materials for byproducts are assumed;

3. Direct labor is related to the time of the production machine;

4. The model complies with government policies, including direct labor overtime and tax cost for carbon dioxide emission; 
5. The direct costs include direct materials, machines, $\mathrm{CO}_{2}$ emission, labor, and electrical power costs;

6. The machine cost of each process is fixed, regardless of any special overtime;

7. The variable costs of other indirect costs are based on the total sales percentage for each product.

\subsection{Notations}

The variables and parameters used in this paper are defined as follows:

$\Omega \quad$ The total profit;

$\mathrm{P} \#_{\mathrm{i}} \quad$ The notation of products;

$\mathrm{P}_{\mathrm{i}} \quad$ The sales unit price of Product i;

$\mathrm{Q}_{\mathrm{i}} \quad$ The sales quantity of the products $\left(\mathrm{PH}_{\mathrm{i}}\right)$;

$\mathrm{US}_{\mathrm{i}} \quad$ The sales upper quantity limit constraint of Product $\mathrm{i}$;

$\mathrm{LS}_{\mathrm{i}} \quad$ The sales lower quantity limit constraints of Product i;

$S_{1}, S_{2} \quad$ The notations for the byproducts for both slag $\left(S_{1}\right)$ and steel-scrap $\left(S_{2}\right)$;

$\mathrm{Q}_{\mathrm{p}} \quad$ The selling quantity of the byproduct;

$\mathrm{K}_{1} \quad$ The unit sales price of the byproduct;

B The amount of input per batch of steel-scrap in the steelmaking process;

$X_{j} \quad$ The number of batches of steel-scrap of the jth level purity in a period;

$\mathrm{M}_{\mathrm{j}} \quad$ The purchase of steel-scrap of the jth level steel purity;

$\mathrm{Mc}_{\mathrm{j}} \quad$ The unit purchase cost of the jth level steel-scrap;

$\mathrm{M}_{2 \mathrm{r}} \quad$ The output of the steel-scrap byproduct $\left(\mathrm{S}_{2}\right)$ in a period

$\mathrm{Mc}_{2 \mathrm{r}} \quad$ The unit cost of the steel-scrap byproduct $\left(S_{2}\right)$;

$\mathrm{R}_{\mathrm{j}}, \mathrm{R}_{\mathrm{j}}{ }^{\prime} \quad$ The output of each batch of $\mathrm{P}_{1}$ using the steel-scrap of the $\mathrm{j}^{\text {th }}$ steel purity level; $\mathrm{R}_{j}{ }^{\prime}$ is the output by enhancing the steel purity of steel-scrap for more value;

$\mathrm{T}_{\mathrm{i}} \quad$ The output of the $\mathrm{i}^{\text {th }}$ product after the steelmaking process;

$\mathrm{H}, \mathrm{H}_{1}, \mathrm{H}_{2} \quad$ The total labor hours $(\mathrm{H})$ including the normal hours $\left(\mathrm{H}_{1}\right)$ and overtime hours $\left(\mathrm{H}_{2}\right)$;

$\mathrm{h}_{1}, \mathrm{~h}_{2}, \mathrm{~h}_{3} \quad$ The direct labor hours for each batch $\left(\mathrm{h}_{1}\right)$ in the steelmaking process and other processes for direct labor hours are per $\mathrm{mt}=1000 \mathrm{~kg}\left(\mathrm{~h}_{2}\right.$ and $\left.\mathrm{h}_{3}\right)$, including in the steel forging process and beam pressing process;

$\mathrm{Lc}, \mathrm{Lc}_{1}, \mathrm{Lc}_{2} \quad$ The total direct labor costs $(\mathrm{Lc})$ including the normal $\left(\mathrm{Lc}_{1}\right)$ and overtime $\left(\mathrm{Lc}_{2}\right)$ direct labor costs;

$\eta_{1}, \eta_{2} \quad\left(\eta_{1}, \eta_{2}\right)$ is an SOS1 (special ordered set of type 1) set of $0-1$ variables within which exactly one variable must be nonzero (Williams 1985);

$\mu_{0}, \mu_{1}, \mu_{2} \quad\left(\mu_{0}, \mu_{1}, \mu_{2}\right)$ is an SOS2 (special ordered set of type 2$)$ set of non-negative variables within which at most two adjacent variables, in the order given to the set, can be nonzero (Williams 1985);

$\theta_{1} \quad$ The wage rate for normal direct labor hours;

$\theta_{2} \quad$ The wage rate for overtime direct labor hours;

$\mathrm{nh} \quad$ The working hours per working day;

nd The working days within a period;

eec $c_{\mathrm{b}} \quad$ The total $\mathrm{CO}_{2}$ emission cost;

eeq $\quad$ The total quantities of $\mathrm{CO}_{2}$ emission;

$\gamma_{1}, \gamma_{2}, \gamma_{3} \quad$ An SOS1 (special ordered set of type 1 ) set of $0-1$ variables within which exactly one variable must be nonzero (Williams 1985);

$\psi_{0}, \psi_{1}, \psi_{2}, \psi_{3} \quad$ An SOS2 (special ordered set of type 2) set of non-negative variables within which at most two adjacent variables, in the order given to the set, can be nonzero (Williams 1985);

$c_{\mathrm{r}} \quad$ The carbon footprint calculated from production batches, which generate the quantity of cr mts carbon footprint emissions;

$\mathrm{r}_{\mathrm{b}} \quad$ The carbon tax rates including a free $\left(\mathrm{r}_{1}\right)$ tax rate and USD2 $\left(\mathrm{r}_{2}\right)$ and USD9 $\left(\mathrm{r}_{3}\right)$ carbon tax rates per $\mathrm{mt}$;

$\mathrm{Fh}_{1}, \mathrm{Fh}_{2}, \mathrm{Fh}_{3} \quad$ The machine hours for each process;

$\mathrm{Dc}_{\mathrm{i}} \quad$ The total direct electricity power cost including batch level in process 1 and unit level in Processes 2 and 3; 
Du The unit cost of $1 \mathrm{KW}$ of electricity power;

$\mathrm{Dn}_{1}, \mathrm{Dn}_{2}, \mathrm{Dn}_{3} \quad$ The electrical power consumed by processes 1,2 , and 3 are $\mathrm{Dn}_{1}, \mathrm{Dn}_{2}$, and $\mathrm{Dn}_{3}$, respectively;

$\mathrm{F}_{\mathrm{i}} \quad$ All machine costs in each process are fixed;

$\mathrm{Oc}_{\mathrm{i}}$ and $\mathrm{pr}_{\mathrm{i}} \quad$ Other indirect cost $\left(\mathrm{Oc}_{\mathrm{i}}\right)$ for product $\mathrm{i}$; allocating its cost based on the percentage of revenue of product $\mathrm{i}\left(\mathrm{pr}_{\mathrm{i}}\right)$.

\subsection{Mathematical Programming Model}

According to Section 4.1, assume that there are six cost categories in the case steel factory, including material cost, labor cost, electrical power cost, $\mathrm{CO}_{2}$ emission cost, machine cost, and other indirect costs The following discusses the combination of related cost elements and the mathematical programming model; then, we can use a LINGO software to obtain the results for determining an optimal decision. In addition, we conduct a scenario profit analysis by gradually increasing the purchase cost of steel-scrap, where steel purity is from the lowest, to middle, to highest level in order to enhance the yield of $\mathrm{P \#}_{1}$ and maximize profit.

\subsubsection{The Model}

The objective is to maximize total profit, $\Omega$ :
Maximize $\Omega=$
(A) Sales amount (A1. Steel products + A2. Slag byproduct)
(B) Direct material cost (B1. Steel-scrap - B2. Recycling the byproduct of steel-scrap)
(C) Direct labor cost (C1. Normal cost + C2. Overtime cost)
(D) Direct electrical power cost
(E) Direct machine cost
(F) $\mathrm{CO}_{2}$ emission (Environmental and social cost)
(G) Other indirect cost

$$
\begin{aligned}
& =\left\{\sum_{\mathrm{i}=1}^{3} \mathrm{P}_{\mathrm{i}} \mathrm{Q}_{\mathrm{i}}+\mathrm{K}_{1} *\left[\sum_{\mathrm{j}=1}^{3} \mathrm{X}_{\mathrm{j}}\left(\mathrm{B}-\mathrm{R}_{\mathrm{j}}\right)\right]\right\}-\left\{\left(\mathrm{B} * \sum_{\mathrm{j}=1}^{3} \mathrm{X}_{\mathrm{j}} * \mathrm{Mc}_{\mathrm{j}}\right)-\left[\left(\sum_{\mathrm{i}=1}^{3} \mathrm{Q}_{\mathrm{i}} / \mathrm{T}_{\mathrm{i}}\right) *\left(1-\mathrm{T}_{\mathrm{i}}\right)\right] *\right. \\
& \left.\mathrm{Mc}_{2 \mathrm{r}}\right\}-\left(\mathrm{Lc}_{1} * \mu_{1}+\mathrm{Lc}_{2} * \mu_{2}\right)-\left\{\mathrm{Du} *\left[\mathrm{Dn}_{1} *\left(\sum_{\mathrm{j}=1}^{3} \mathrm{X}_{\mathrm{j}}\right)+\left(\mathrm{Dn}_{2} * \mathrm{Q}_{2}\right)+\left(\mathrm{Dn}_{3} * \mathrm{Q}_{3}\right)\right]\right\}- \\
& \sum_{\mathrm{i}=1}^{3} \mathrm{~F}_{\mathrm{i}}-\left(\mathrm{eec}_{1} * \psi_{1}+\mathrm{eec}_{2} * \psi_{2}+\mathrm{eec}_{3} * \psi_{3}\right)-\sum_{\mathrm{i}=1}^{3} \mathrm{Oc}_{\mathrm{i}}
\end{aligned}
$$

which is subject to

\section{A. Product sales upper limit constraints}

$$
\mathrm{Q}_{\mathrm{i}} \leqq \mathrm{US}_{\mathrm{i}}
$$

Product sales lower limit constraints

$$
\mathrm{Q}_{\mathrm{i}} \geqq \mathrm{LS}_{\mathrm{i}}
$$

B1. Direct material quantity constraints

$$
\mathrm{B} * \sum_{\mathrm{j}=1}^{3} \mathrm{X}_{\mathrm{j}} * \mathrm{R}_{\mathrm{j}}=\sum_{\mathrm{i}=1}^{3}\left(\mathrm{Q}_{\mathrm{i}} / \mathrm{T}_{\mathrm{i}}\right)
$$

C. Direct labor hour constraints

$$
\begin{gathered}
\mathrm{H}=\mathrm{H}_{1} \mu_{1}+\mathrm{H}_{2} \mu_{2}, \\
\left(\sum_{\mathrm{j}=1}^{3} \mathrm{X}_{\mathrm{j}}\right) * \mathrm{~h}_{1}+\left(\mathrm{Q}_{2} / \mathrm{T}_{2}\right) * \mathrm{~h}_{2}+\left(\mathrm{Q}_{3} / \mathrm{T}_{3}\right) * \mathrm{~h}_{3}=\mathrm{H}_{1} \mu_{1}+\mathrm{H}_{2} \mu_{2}, \\
\mu_{0}-\eta_{1} \leqq 0, \\
\mu_{1}-\eta_{1}-\eta_{2} \leqq 0, \\
\mu_{2}-\eta_{2} \leqq 0,
\end{gathered}
$$




$$
\begin{aligned}
\mu_{0}+\mu_{1}+\mu_{2}=1, & 0 \leqq \mu_{0}, \mu_{1}, \mu_{2} \leqq 1 \\
\eta_{1}+\eta_{2}=1, & \eta_{1}, \eta_{2}=0,1,
\end{aligned}
$$

E. Machine hour constraints

$$
\mathrm{Fh}_{1} \leqq \mathrm{nh} * \mathrm{nd} ; \quad \mathrm{Fh}_{2} \geqq \mathrm{Q}_{2} * \mathrm{~h}_{2} ; \quad \mathrm{Fh}_{3} \geqq \mathrm{Q}_{3} * \mathrm{~h}_{3},
$$

F. $\mathrm{CO}_{2}$ emission constraints

$$
\begin{gathered}
\left(B * \sum_{j=1}^{3} X_{j}\right) * \text { cr }=\text { eeq }_{1} * \psi_{1}+\text { eeq }_{2} * \psi_{2}+\text { eeq }_{3} * \psi_{3}, \\
\text { eeq }=\text { eeq }_{1}{ }^{*} \psi_{1}+\text { eeq }_{2}{ }^{*} \psi_{2}+\text { eeq }_{3}{ }^{*} \psi_{3} \\
\psi_{0}-\gamma_{1} \leq 0 \\
\psi_{1}-\gamma_{1}-\gamma_{2} \leq 0, \\
\psi_{2}-\gamma_{2}-\gamma_{3} \leq 0 \\
\psi_{3}-\gamma_{3} \leq 0 \\
\psi_{0}+\psi_{1}+\psi_{2}+\psi_{3}=1,0 \leq \psi_{0}, \psi_{1}, \psi_{2}, \psi_{3} \leq 1, \\
\gamma_{1}+\gamma_{2}+\gamma_{3}=1, \gamma_{1}, \gamma_{2}, \gamma_{3}=0,1
\end{gathered}
$$

\subsubsection{Sales Amount}

According to Figure 5, the sales amount comes from the following products: steel billets $\left(\mathrm{P}_{1}\right)$, steel reinforcing bars $\left(\mathrm{P}_{2}\right)$, and $\mathrm{H}$ beams $\left(\mathrm{P}_{3}\right)$, which are produced in the different processes. In the production of steel billets $\left(\mathrm{P} \#_{1}\right)$, slag byproduct $\left(\mathrm{S}_{1}\right)$ can be produced and sold. In this paper, the weight of the input batch of raw material in process 1 must be equaled to $100 \mathrm{mts}$ (B) regardless of the steel purity $\left(\mathrm{M}_{\mathrm{j}}\right)$ of every batch because of the capacity of the furnace. On the other hand, the total number of batches in a period is $X_{j}$, which includes different $j$ levels that will affect the number of output $P \#_{1}$ $\left(R_{j}\right)$ and byproduct $S_{1}\left(B-R_{j}\right)$ per batch. Assume also that $Q_{i}$ is the selling quantity of product $P \#_{i}$. The quantity of byproduct $\left[\mathrm{X}_{j}\left(B-R_{j}\right)\right]$ is the difference in the quantity between the input quantity of the steel-scrap and the output of the steel billet $\left(\mathrm{P \#}_{1}\right)$. In this case, the steel-scrap has $\mathrm{j}$ kinds of steel purity levels and j equals 3. Therefore, the total sales amount in Equation (1), i.e., $\sum_{i=1}^{3} P_{i} Q_{i}$ and $K_{1} *$ $\left[X_{j}\left(B-R_{j}\right)\right]$ represent the total sales amount of products and byproducts, respectively. Furthermore, the products may have sales upper limit constraints $\left(\mathrm{Q}_{\mathrm{i}} \leqq \mathrm{US}_{\mathrm{i}}\right)$ due to market demand limits, as shown in Equation (2); the products may also have lower sales limit constraints $\left(Q_{i} \geqq L S_{i}\right)$, as shown in Equation (3), due to considering the economics of scale or satisfying the original customers' needs.

\subsubsection{Direct Material Cost}

The second term in Equation (1), i.e., $\left\{\left[\mathrm{B} *\left(\sum_{\mathrm{j}=1}^{3} \mathrm{X}_{\mathrm{j}} * \mathrm{Mc}_{\mathrm{j}}\right)\right]-\left[\left(\sum_{\mathrm{i}=1}^{3} \mathrm{Q}_{\mathrm{i}} / \mathrm{T}_{\mathrm{i}}\right) *\left(1-\mathrm{T}_{\mathrm{i}}\right)\right] * \mathrm{Mc}_{2 \mathrm{r}}\right\}$, stands for the total direct material cost by purchasing steel-scrap and saving the material cost due to recycling steel-scrap byproducts. Firstly, Equation (4), i.e., $\left(B * \sum_{j=1}^{3} X_{j} * R_{j}\right)=\left(\sum_{i=1}^{3} Q_{i} / T_{i}\right)$, is the quantity of material associated with different steel purity levels in the steel-scrap that is equal to the total sales quantity of products $1-3\left(\mathrm{P}_{1}, \mathrm{P}_{2}\right.$, and $\left.\mathrm{P} \#_{3}\right)$. In this subsection, $\mathrm{B}, \mathrm{X}_{\mathrm{j}}$, and $\mathrm{R}_{\mathrm{j}}$, as described in the above Section 4.4.2. Sales Amount), and $\mathrm{Mc}_{\mathrm{j}}$ are the unit costs of steel-scrap at the $\mathrm{j}^{\text {th }}$ purity level; thus, the total cost of the direct material for the purchase of steel-scrap is $\left(B * \sum_{j=1}^{3} X_{j} * M c_{j}\right)$ Secondly, the byproduct of recycled steel-scrap is from Process 2 and Process 3. The $Q_{i}$ was also introduced in the above Section 4.4.2. Sales Amount), and $\mathrm{T}_{\mathrm{i}}$ is the output of $\mathrm{P}_{\mathrm{i}}$ in the production process. Additionally, $\mathrm{Mc}_{2 \mathrm{r}}$ is the byproduct of steel-scrap $\left(\mathrm{S}_{2}\right)$ recycled from Processes 2 and 3, and the unit cost of $\mathrm{S}_{2}$ is fixed; 
thus, $\left[\sum_{\mathrm{i}=1}^{3} \mathrm{Q}_{\mathrm{i}} / \mathrm{T}_{\mathrm{i}} *\left(1-\mathrm{T}_{\mathrm{i}}\right) * \mathrm{Mc}_{2 \mathrm{r}}\right]$ is the cost of the direct material for the byproduct of steel-scrap $\left(\mathrm{S}_{2}\right)$. To sum up, the direct material cost is the second term in Equation (1), i.e., $\left\{\left[\mathrm{B} * \sum_{\mathrm{j}=1}^{3} \mathrm{X}_{\mathrm{j}} * \mathrm{Mc}_{\mathrm{j}}\right)-\right.$ $\left.\left[\left(\sum_{\mathrm{i}=1}^{3} \mathrm{Q}_{\mathrm{i}} / \mathrm{T}_{\mathrm{i}}\right) *\left(1-\mathrm{T}_{\mathrm{i}}\right)\right] * \mathrm{Mc}_{2 \mathrm{r}}\right\}$

\subsubsection{Direct Labor Cost}

Figure 6 shows a piecewise linear cost function, which represents that labor hours can be expanded to overtime; thus, the labor cost rate will also increase. In the normal working hour range, the highest labor hour and cost are $\mathrm{H}_{1}$ and $\mathrm{Lc}_{1}$, respectively. In the overtime labor hour range, the highest overtime labor hour and cost are $\mathrm{Lc}_{2}$ and $\mathrm{H}_{2}$, respectively. However, the total labor hour (normal + overtime) is represented in Equation (5): $\mathrm{H}=\mathrm{H}_{1} \mu_{1}+\mathrm{H}_{2} \mu_{2}$. On the other hand, the associated total direct labor cost is shown in the third term in Equation (1), i.e., $\mathrm{Lc}_{1} \mu_{1}+\mathrm{Lc}_{2} \mu_{2}$.

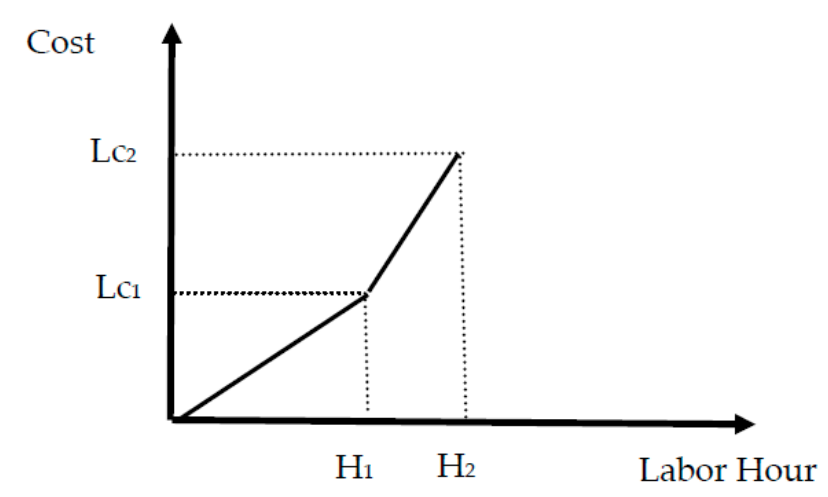

Figure 6. A piecewise linear function for direct labor.

For direct labor hours, the associated constraints are shown in Equations (5)-(11). Particularly, the direct labor hours in each process (Processes 1-3 as in Figure 5) are shown in Equation (6), which is also equal to Equation (5).

$\left(\eta_{1}, \eta_{2}\right)$ in Equation (11) is an SOS1 set of 0-1 variables, where only one variable will be one. $\eta_{1}$ and $\eta_{2}$ are indicator variables; if $\eta_{1}=1$, it means that the data point will fall within the first segment of Figure 6, and if $\eta_{2}=1$, it means that the data point will fall within the second segment of Figure 6 . On the other hand, $\left(\mu_{0}, \mu_{1}, \mu_{2}\right)$ in Equation (10) is an SOS2 set of non-negative variables, within which at the most two adjacent, in the order given to the set, can be nonzero (Williams 1985). In Equations (7)-(11), if $\eta_{1}=1$, then $\eta_{2}=0$ from Equation (11), $\mu_{2}=0$ from Equation (9), $\mu_{0}, \mu_{1} \leqq 1$ from Equations (7) and (8), and $\mu_{0}+\mu_{1}=1$ from Equation (10). It means that the data point will be the linear combination of points $(0,0)$ and $\left(\mathrm{H}_{1}, \mathrm{Lc}_{1}\right)$; the labor hours used and the associated labor costs will be $\mathrm{H}_{1} \mu_{1}$ and $\mathrm{Lc}_{1} \mu_{1}$, respectively. Similarly, if $\eta_{2}=1$, then $\eta_{1}=0$ from Equation (11), $\mu_{0}=0$ from Equation (8), $\mu_{1}, \mu_{2} \leqq 1$ from Equations (8) and (9), and $\mu_{1}+\mu_{2}=1$ from Equation (10). Thus, the data point will be the linear combination of points $\left(\mathrm{H}_{1}, \mathrm{Lc}_{1}\right)$ and $\left(\mathrm{H}_{2}, \mathrm{Lc}_{2}\right)$; the labor hours used and the associated labor costs will be $\left(\mathrm{H}_{1} \mu_{1}+\mathrm{H}_{2} \mu_{2}\right)$ and $\left(\mathrm{Lc}_{1} \mu_{1}+\mathrm{Lc}_{2} \mu_{2}\right)$ as shown in Equation (5) and the third term of Equation (1), respectively.

\subsubsection{Direct Electricity Power Cost}

In this subsection, the direct electricity power $\operatorname{cost}\left(\mathrm{Dc}_{\mathrm{i}}\right)$ is divided into two parts, one by batch in process 1 and another by the unit of $m t$ in Processes 2 and 3. The fourth term in Equation (1), i.e., $\left\{\mathrm{Du} *\left[\mathrm{Dn}_{1} *\left(\sum_{\mathrm{j}=1}^{3} \mathrm{X}_{\mathrm{j}}\right)\right]\right\}$, and $\left\{\mathrm{Du} *\left[\left(\mathrm{Dn}_{2} * \mathrm{Q}_{2}\right)+\left(\mathrm{Dn}_{3} * \mathrm{Q}_{3}\right)\right]\right\}$ represent the total direct electricity power cost of this case. Du is the unit cost of electricity power. $\mathrm{Dn}_{1}$ is the quantity of electricity power used for each batch in process 1 , and $\mathrm{Dn}_{2}$ and $\mathrm{Dn}_{3}$ are the quantities of electricity power used in Processes 2 and 3 per mt. 


\subsubsection{Machine Costs}

The total cost of the machines in each process is fixed, regardless of whether the machines are used during non-normal working hours. The fifth term in Equation (1), i.e., $\sum_{i=1}^{3} F_{i}$ represents the total cost of machines in all processes (Processes 1-3 as shown in Figure 3).

\subsection{7. $\mathrm{CO}_{2}$ Emission Costs}

In the literature of recent years, carbon tax cost has received considerable attention in various industries such as the construction industry [3,41], the electrical and electronic industry [42], the pharmaceutical industry [43], the tire industry [44-46], the textile industry [47], the knitted footwear industry [48,49], the paper industry [50], the aluminum-alloy wheel industry [51], and so on. The sixth term in Equation (1), eec $1 * \psi_{1}+\operatorname{eec}_{2} * \psi_{2}+\operatorname{eec}_{3} * \psi_{3}$, represents the total $\mathrm{CO}_{2}$ emission cost (i.e., carbon tax cost). The steelmaking process, studied in this paper, has successfully operated the manufacturing technology of EAF and adopts the recycling material of steel-scrap to produce the $\mathrm{P \#}_{1}$ steel billets. The factory disclosed the carbon footprint information for each product to identify and implement the philosophies of the energy-conserving design and low-carbon emissions [22], which have the purpose of proactively and actively promoting $\mathrm{CO}_{2}$ emissions reduction. According to the concept of the Corporate Social Responsibility (CSR) of a public company and its carbon footprint as a strong tool, the quantity of $\mathrm{CO}_{2}$ emission from the steelmaking process is determined and estimated [22,23]. The manufacturing technology of EAF supports lower $\mathrm{CO}_{2}$ emission quantities and a tax policy.

Regarding the quantities of $\mathrm{CO}_{2}$ emissions, the associated constraints are expressed in Equations (13)-(20). In Equation (13), the total amount of $\mathrm{CO}_{2}$ emissions is divided into three segments with different constraint quantities, as shown in Equation (14), as well as different tax rates. It is a piecewise linear cost function for the carbon tax cost function, as shown in Figure 6.

$\left(\gamma_{1}, \gamma_{2}, \gamma_{3}\right)$ in Equation (20) is an SOS1 set of 0-1 variables, where only one variable will be one. $\gamma_{1}, \gamma_{2}$, and $\gamma_{3}$ are indicator variables; if $\gamma_{1}=1$, it means that the data point will fall within the first segment of Figure 6; similarly, if $\gamma_{2}=1$ or $\gamma_{3}=1$, it means that the data point will fall within the second or third segment of Figure 6. On the other hand, $\left(\psi_{0}, \psi_{1}, \psi_{2}, \psi_{3},\right)$ in Equation (19) is an SOS2 set of non-negative variables, within which at most two adjacent, in the order given to the set, can be nonzero (Williams 1985).

If $\gamma_{1}=1$, then $\gamma_{2}=\gamma_{3}=0$ from Equation (20), $\psi_{2}=\psi_{3}=0$ from Equations (17) and (18), $\psi_{0} \leqq 1$ and $\psi_{1} \leqq 1$ from Equations (15) and (16), and $\psi_{0}+\psi_{1}=1$ from Equation (19). It means that the data point will fall within the first segment of Figure 7 . Then, the total quantity of $\mathrm{CO}_{2}$ emission is eeq $\leqq$ eeq 1 , and the carbon tax cost is 0 , since eec ${ }^{*} \psi_{1}+\operatorname{eec}_{2}{ }^{*} \psi_{2}+\operatorname{eec}_{3}{ }^{*} \psi_{3}=00^{*} \psi_{1}+\operatorname{eec}_{2}{ }^{*} 0+\operatorname{eec}_{3}{ }^{*} 0=0$. This means that the data point $\left(\right.$ eeq $\left._{1} \psi_{1}, 0\right)$ in the first segment of Figure 7 is the linear combination of $(0,0)$ and $\left(\mathrm{eeq}_{1}, 0\right)$.

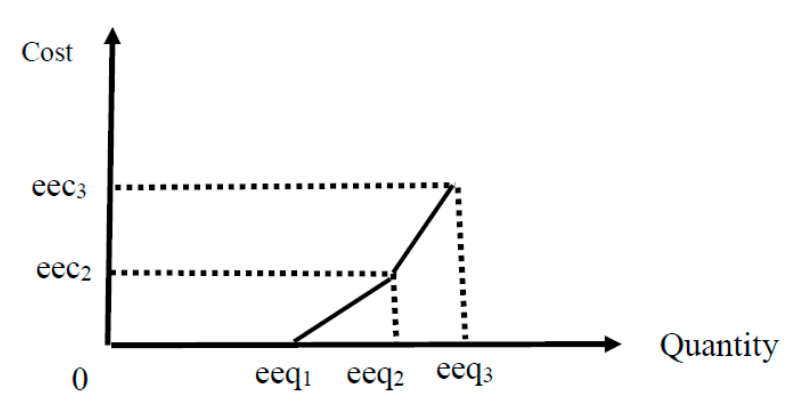

Figure 7. $\mathrm{CO}_{2}$ emission costs.

If $\gamma_{2}=1$, then $\gamma_{1}=\gamma_{3}=0$ from Equation (20), $\psi_{0}=\psi_{3}=0$ from Equations (15) and (18), $\psi_{1} \leqq 1$ and $\psi_{2} \leqq 1$ from Equations (16) and (17), and $\psi_{1}+\psi_{2}=1$ from Equation (19). It means that the data point will fall within the second segment of Figure 7 . Then, the total quantity of $\mathrm{CO}_{2}$ emissions is eeq $_{\mathrm{b}}=$ eeq $_{1}{ }^{*} \psi_{1}+$ eeq $_{2}{ }^{*} \psi_{2}$ from Equation (14), and the carbon tax cost is $\operatorname{eec}_{1}{ }^{*} \psi_{1}+\operatorname{eec}_{2}{ }^{*} \psi_{2}+\operatorname{eec}_{3}{ }^{*} \psi_{3}=$ 
$0^{*} \psi_{1}+\operatorname{eec}_{2}{ }^{*} \psi_{2}+\operatorname{eec}_{3}{ }^{*} 0=\operatorname{eec}_{2}{ }^{*} \psi_{2}$ from Equation (1). This means that the data point $\left(\operatorname{eeq}_{1} \psi_{1}+\right.$ eeq $_{2} \psi_{2}$, eec $\left._{2} \psi_{2}\right)$ in the second segment of Figure 7 is the linear combination of $\left(\mathrm{eeq}_{1}, 0\right)$ and $\left(\mathrm{eeq}_{2}, \mathrm{eec}_{2}\right)$.

If $\gamma_{3}=1$, then $\gamma_{1}=\gamma_{2}=0$ from Equation (20), $\psi_{0}=\psi_{1}=0$ from Equations (15) and (16), $\psi_{2} \leqq 1$ and $\psi_{3} \leqq 1$ from Equations (17) and (18), and $\psi_{2}+\psi_{3}=1$ from Equation (19). It means that the data point will fall within the third segment of Figure 7. Then, the total quantity of $\mathrm{CO}_{2}$ emissions is eeqb $=$ eeq $_{2}{ }^{*} \psi_{2}+$ eeq $_{3}{ }^{*} \psi_{3}$ from Equation (14), and the carbon tax cost is $\operatorname{eec}_{1}{ }^{*} \psi_{1}+\operatorname{eec}_{2}{ }^{*} \psi_{2}+\operatorname{eec}_{3}{ }^{*} \psi_{3}=0^{*} 0+$ $\operatorname{eec}_{2}{ }^{*} \psi_{2}+\operatorname{eec}_{3}{ }^{*} \psi_{3}=\operatorname{eec}_{2}{ }^{*} \psi_{2}+\operatorname{eec}_{3}{ }^{*} \psi_{3}$ from Equation (1). This means that the data point (eeq ${ }^{*} \psi_{2}+$ eeq $_{3}{ }^{*} \psi_{3}$, eec $\left._{2}{ }^{*} \psi_{2}+\operatorname{eec}_{3}{ }^{*} \psi_{3}\right)$ in the third segment of Figure 7 is the linear combinations of (eeq 2 , eec 2$)$ and $\left(\mathrm{eeq}_{3} \text {, eec }\right)_{3}$. In brief, if the company emits more $\mathrm{CO}_{2}$, then the company will pay the higher carbon tax rate.

\subsubsection{Other Indirect Cost}

The seventh term in Equation (1), i.e., $\sum_{\mathrm{i}=1}^{3} \mathrm{Oc}_{\mathrm{i}}$, represents the total amount of other indirect costs which are allocated by the percentage of revenue of product $i\left(\mathrm{pr}_{\mathrm{i}}\right)$.

\section{Illustrative Case Study and Discussion}

This section presents a numerical example and illustrates the application of the model proposed in this paper. The illustrative example data are shown in Table 2. The case company is considering producing products 1,2 , and $3\left(\mathrm{P}_{4}\right.$ including $\mathrm{P}_{1}, \mathrm{P}_{2}$, and $\left.\mathrm{P} \#_{3}\right)$. We assume that they need three main activities, including one batch-level in Process 1 for $\mathrm{P \#}_{1}$ and two unit-levels in Processes 2 and 3 for $\mathrm{P \#}_{2}$ and $\mathrm{P} \#_{3}$. In process 1 , we can choose the purity level of $\mathrm{M}_{\mathrm{j}}$ steel for steel-scrap, and $\mathrm{M}_{\mathrm{j}}$ includes $\mathrm{M}_{1}, \mathrm{M}_{2}$, and $\mathrm{M}_{3}$. The following example displays the revenue and various costs.

Table 2. Example data (Case 1).

\begin{tabular}{|c|c|c|c|c|c|c|}
\hline Description & \multicolumn{3}{|c|}{ Material $\left(M_{j}\right)$ for $P \#_{1}$} & \multicolumn{3}{|c|}{ Products $\left(P \#_{i} / S_{1}\right)$} \\
\hline $\begin{array}{l}\text { Sales } \\
\text { Demand }\left(\mathrm{Q}_{\mathrm{i}}\right) / \mathrm{mts} \\
\text { Products price }\left(\mathrm{P}_{\mathrm{i}}\right) / \mathrm{USD} \\
\text { Byproduct price }\left(\mathrm{K}_{1}\right) / \mathrm{USD}\end{array}$ & & & & $\begin{array}{l}\mathrm{P} \#_{1} / \mathrm{S}_{1} \\
2000 \leqq \mathrm{Q}_{1} \leqq 4000 \\
\$ 450 \\
\$ 12\end{array}$ & $\begin{array}{l}\mathrm{P \#}_{2} \\
\mathrm{Q}_{2} \geq 3500 \\
\$ 580\end{array}$ & $\begin{array}{l}\mathrm{P}_{3} \\
\mathrm{Q}_{3} \geq 3500 \\
\$ 660\end{array}$ \\
\hline $\begin{array}{l}\text { Direct Material } \\
\text { Unit price }\left(\mathrm{Mc}_{\mathrm{j}}\right) / \mathrm{mt} / \mathrm{USD} \\
\text { Total batches }\left(\mathrm{X}_{\mathrm{j}}\right) / 100 \mathrm{mts} \\
\text { Output } \mathrm{P \#}_{1}\left(\mathrm{R}_{\mathrm{i}}\right) / 1 \text { batch }(\mathrm{B}) \\
\text { Output } \mathrm{S}_{1}\left(\mathrm{~B}-\mathrm{R}_{\mathrm{i}}\right) / 1 \text { batch }(\mathrm{B}) \\
\mathrm{P}_{1} \text { for selling Products }\left(\mathrm{T}_{\mathrm{i}}\right) / \mathrm{mt} \\
\text { Transfer } \mathrm{P \#}_{1}\left(\mathrm{Q}_{\mathrm{i}} / \mathrm{T}_{\mathrm{i}}\right) / \mathrm{mts} \text { to } \\
\text { others process } \\
\text { Recycling the } \mathrm{S}_{2} \text { byproduct } \\
\left(\mathrm{Q}_{\mathrm{i}} / \mathrm{T}_{\mathrm{i}}\right)-\mathrm{Q}_{\mathrm{i}} / \mathrm{mts} \\
\mathrm{Unit}_{2} \text { byproduct cost } \\
\left(\mathrm{Mc}_{2 \mathrm{r}}\right) / \mathrm{mt} / \mathrm{USD}\end{array}$ & $\begin{array}{l}\mathrm{M}_{1} \\
\$ 300 \\
\mathrm{X}_{1} \leqq 65 \\
\mathrm{R}_{1}=88 \\
12\end{array}$ & $\begin{array}{l}\mathrm{M}_{2} \\
\$ 317 \\
\mathrm{X}_{2} \leqq 65 \\
\mathrm{R}_{2}=91 \\
9\end{array}$ & $\begin{array}{l}\mathrm{M}_{3} \\
\$ 330 \\
\mathrm{X}_{3} \leqq 65 \\
\mathrm{R}_{3}=94 \\
6\end{array}$ & $\begin{array}{l}1 \\
\mathrm{Q}_{1} / \mathrm{T}_{1}\end{array}$ & $\begin{array}{l}0.96 \\
\mathrm{Q}_{2} / \mathrm{T}_{2} \\
\left(\mathrm{Q}_{2} / \mathrm{T}_{2}\right)-\mathrm{Q}_{2} \\
\$ 322\end{array}$ & $\begin{array}{l}0.98 \\
\mathrm{Q}_{3} / \mathrm{T}_{3} \\
\left(\mathrm{Q}_{3} / \mathrm{T}_{3}\right)-\mathrm{Q}_{3} \\
\$ 322\end{array}$ \\
\hline $\begin{array}{l}\text { Direct Labor } \\
\text { Cost/USD } \\
\text { Labor hours } \\
\text { Wage rate/USD }\end{array}$ & & & & $\begin{array}{l}\mathrm{Lc}_{1}=\$ 66,000 ; \mathrm{Lc}_{2} \\
\mathrm{H}_{1}=10,000 ; \mathrm{H}_{2}=1 \\
\theta_{1}=\$ 6.6 ; \theta_{2}=9.9\end{array}$ & $\begin{array}{l}05,600 \\
00\end{array}$ & \\
\hline $\begin{array}{l}\text { Electrical power } \\
\text { Each batch level } 0.75 \\
\text { hours/KW } \\
\text { Unit level hours/mt } \\
1 \mathrm{KW}\left(\mathrm{D}_{\mathrm{u}}\right) \text { cost/USD }\end{array}$ & & & & $\begin{array}{l}45 \\
85\end{array}$ & $\begin{array}{l}0.1 \\
85\end{array}$ & $\begin{array}{l}0.1 \\
85\end{array}$ \\
\hline $\begin{array}{l}\text { Machine } \\
\text { Machine hours }\left(\mathrm{Fh}_{\mathrm{i}}\right) \\
\text { Machine cost }\left(\mathrm{F}_{\mathrm{i}}\right) / \mathrm{USD}\end{array}$ & & & & $\begin{array}{l}\mathrm{Fh}_{1} \leqq 176 \\
\mathrm{~F}_{1}=\$ 100,000\end{array}$ & $\begin{array}{l}\mathrm{Fh}_{2}=\mathrm{Q}_{2} \\
\mathrm{~F}_{2}=\$ 50,000\end{array}$ & $\begin{array}{l}\mathrm{Fh}_{3}=\mathrm{Q}_{3} \\
\mathrm{~F}_{3}=\$ 150,000\end{array}$ \\
\hline $\begin{array}{l}\mathrm{CO}_{2} \text { Emission } \\
\text { Carbon cost }\left(\mathrm{eec}_{\mathrm{b}}\right) \\
\text { Carbon } \mathrm{Q}^{\prime} \text { ty }\left(\mathrm{eeq}_{\mathrm{b}}\right) \\
\text { Carbon rate }(\mathrm{cr}) / \mathrm{batch} \\
\text { Unit carbon }\left(\mathrm{r}_{\mathrm{b}}\right) / \mathrm{USD}\end{array}$ & $\begin{array}{l}\text { eec }_{1}=\$ 0 \\
\text { eeq }_{1}=30 \\
\mathrm{cr}=40 \\
\mathrm{r}_{1}=\$ 0 ; \mathrm{r}\end{array}$ & $\begin{array}{l}\operatorname{eec}_{2}=\$ 20 \\
0 ; \text { eeq }_{2}= \\
=\$ 2 ; r_{3}=\end{array}$ & $\begin{array}{l}0 ; \text { eec }_{3}=\$ 2 \\
00 ; \text { eeq }_{3}= \\
9\end{array}$ & 000 & & \\
\hline $\begin{array}{l}\text { Other indirect costs } \\
\mathrm{Oc}_{\mathrm{i}}\end{array}$ & & & & $3 \% * \mathrm{Q}_{1} * \mathrm{P}_{1}$ & $5 \% * \mathrm{Q}_{2} * \mathrm{P}_{2}$ & $5 \% * \mathrm{Q}_{3} * \mathrm{P}_{3}$ \\
\hline
\end{tabular}




\subsection{Sales Amount}

The first part is the revenue, including the three kinds of products of steel billets $\left(\mathrm{P} \#_{1}\right)$, steel reinforcing bars $\left(\mathrm{P}_{2}\right)$, and $\mathrm{H}$ beams $\left(\mathrm{P} \#_{3}\right)$, which have the unit prices $\left(\mathrm{P}_{\mathrm{i}}\right)$ of USD450 $\left(\mathrm{P}_{1}\right)$, USD580 $\left(\mathrm{P}_{2}\right)$, and USD660 $\left(\mathrm{P}_{3}\right)$, respectively. The second part is the revenue of the byproduct slag $\left(\mathrm{S}_{1}\right)$, and the unit price is USD12 $\left(\mathrm{K}_{1}\right)$. Additionally, in Process 1, the quantity of input raw material per batch of steel-scrap is limited to 100 (B) $m$ ts and the same steel purity level $\left(\mathrm{M}_{\mathrm{j}}\right)$ for every batch, and each $\mathrm{j}^{\text {th }}$ level of steel-scrap does not exceed the number of $65\left(\mathrm{X}_{\mathrm{j}}\right)$ batches in a period, which is due to the capacity of the furnace. The output quantity of $\mathrm{P \#}_{1}$ in each batch depends on the different steel purity levels $\left(M_{j}\right)$ of the steel-scrap, and their output of $R_{j}$ includes $88\left(R_{1}\right), 91\left(R_{2}\right)$, and $94\left(R_{3}\right)$ per batch. On the other hand, only the amount of byproduct $\left[X_{j} *\left(B-R_{j}\right)\right]$ in process 1 in a period is the difference between the input quantity of steel-scrap raw material $\left(X_{j} * B\right)$ and the output $P \#_{1}\left(X_{j} * R_{j}\right)$. To sum up, the total revenue is expressed, as shown in Equation (1), as $\left\{\sum_{i=1}^{3} P_{i} Q_{i}+K_{1} *\left[\sum_{j=1}^{3} X_{j} *\left(B-R_{j}\right)\right]\right\}$. We also consider the quantity of sales constraints for each product in the operational policy; product $\mathrm{P}_{1}$ can only sell the quantity of $\mathrm{Q}_{1}$ between $2000\left(\mathrm{LS}_{1}\right)$ and $4000\left(\mathrm{US}_{1}\right)$ due to market constraints and customers' needs, while the quantities of other products, $\mathrm{Q}_{2}$ and $\mathrm{Q}_{3}$, should be more than $3500\left(\mathrm{LS}_{2}\right.$ and $\left.\mathrm{LS}_{3}\right) \mathrm{mts}$.

\subsection{Direct Material}

The direct material of steel-scrap is purchased from the steel recycling industry or obtained from the steel-scrap byproducts from Processes 2 and 3 . The following introduces the sources of steel-scrap in two ways, external procurement and an internal production byproduct.

\subsubsection{Purchasing the Recycling Materials of Steel-Scrap and Producing Products}

EAF adopts the recycling material of steel-scrap to produce the $\mathrm{P}_{1}$ product. The purchase of steel-scrap not only conforms to the capacity of EAF but also considers the process of pouring steel-scrap of different dimensions into the EAF. The scrap-steel of different dimensions may include light, heavy, or small, and the various steel-scraps are poured into an EAF through its hopper and pipe to efficiently batch-produce product $\mathrm{P}_{1}$.

Surprisingly, steel-scrap is recycled from garbage or completely irregular shapes of scrapped equipment. For example, the garbage of steel-scrap is usually supplied from household goods, including furniture, cans, utensils, etc. Another kind of steel-scrap comes from various waste equipment, such as automobile, ships, tools, machines, buildings, and other scraped equipment. All raw steel-scraps are mixed with lots of soil, cement, sticky sand, clay, rubber, paint, etc. However, the usable steel-scraps for the EAF must be clean, cut, and crushed through different machines in a steel recycling industry. In addition, steel firms have to request that suppliers in the steel recycling industry classify their steel-scrap recycling materials as light, heavy, or small dimensions to meet the pouring process of their EAF.

In this case, the steel-scraps of different steel purity $\left(\mathrm{M}_{\mathrm{j}}\right)$ can be used as raw material to produce steel products. The following numerals assume that the purchase of steel-scrap focuses only on steel purity and will affect the yield of steel billets $\left(\mathrm{PH}_{1}\right)$ and slag byproducts $\left(\mathrm{S}_{1}\right)$ in the steelmaking process. Green steelmaking manufacturing must conduct a good analysis of procurement, have production policies, and make decisions to maximize profit through a LINGO software.

1. Assume that producing $P \#_{1}$ can use three kinds of direct materials-steel-scrap $\mathrm{M}_{\mathrm{j}}\left(\mathrm{M}_{1}, \mathrm{M}_{2}\right.$, and $\mathrm{M}_{3}$ ). The input material of product $\mathrm{P} \#_{2}$ in Process 2 and $\mathrm{P} \#_{3}$ in Process 3 come only from the P\# (semi-manufactured goods called $\mathrm{P}_{1}$ ). We also assume that the plant needs three main activities to produce these three products $\left(\mathrm{PH}_{1}, \mathrm{P \# _{2 }}\right.$, and $\left.\mathrm{P} \#_{3}\right)$, as shown in Figure 5 in Section 4.1.

2. In process 1 , inputting the steel-scrap of $\mathrm{M}_{\mathrm{j}}$ into the $\mathrm{EAF}$ is for the production of $\mathrm{P} \#_{1}$ and $\mathrm{S}_{1}$. $\mathrm{P} \#_{1}$, which not only can be sold but also can produce other products $\left(\mathrm{P}_{2}\right.$ and $\left.\mathrm{P} \#_{3}\right)$. For other products, meaning the semi-manufactured goods, $\mathrm{P}_{1}$ must be transferred to other processes; one into 
Process 2 for producing $\mathrm{P \#}_{2}$, another into Process 3 for producing $\mathrm{P}_{3}$. Additionally, byproduct $\mathrm{S}_{2}$ will be produced in two Processes, namely, 2 and 3 . The byproduct $\mathrm{S}_{2}$ will become a recycled material of steel-scrap, just as the $\mathrm{M}_{2 \mathrm{r}}$, and assume that the unit cost of $\mathrm{Mc}_{2 \mathrm{r}}$ is equal to USD322 each $\mathrm{mt}$.

3. For the production of $\mathrm{P}_{1}$, the purchase of three kinds of steel-scrap recycled materials $\mathrm{M}_{\mathrm{j}}\left(\mathrm{M}_{1}\right.$, $M_{2}$, and $M_{3}$ ) are divided into 3 steel purity levels of the $M_{1}$ lowest, $M_{2}$ middle, and $M_{3}$ highest levels, and the unit costs are USD300 ( $\left.\mathrm{Mc}_{1}\right)$, USD317 $\left(\mathrm{Mc}_{2}\right)$, and USD330 $\left(\mathrm{Mc}_{3}\right)$, respectively. However, different levels of steel purity per batch $(B=100)$ will affect the yield of $P \#_{1}$ and $S_{1}$ in Process 1 , which range from 88,91 , to $94 \mathrm{mts}$ and from 12,9 , to $6 \mathrm{mts}$, respectively.

\subsection{Direct Labor}

In a period, in Process 1, we assume that 14 workers work only normal times, including 8 hours each day and 22 working days. Each batch needs direct labor for $h_{1}$ hours (17.5 hours), including 14 workers and 1.25 hours of working together.

According to a report by the AISI (American Iron \& Steel Institute), the labor productivity per $\mathrm{mt}$ of finished steel is from 10.1 hours in the early 1980s to 1.9 hours in 2015 [20]. In future smart manufacturing, the labor productivity per $\mathrm{mt}$ of finished steel will improve to one hour $\left(\mathrm{h}_{2}\right.$ or $\left.\mathrm{h}_{3}\right)$ in Processes 2 and 3.

In terms of normal direct labor hours, $\mathrm{H}_{1}$ is 10,000 labor hours with a wage rate of USD6.6 $\left(\theta_{1}\right)$ per hour and expands the number of labor hours to $\mathrm{H}_{2}=14,000$ with an overtime wage rate of USD9.9 $\left(\theta_{2}\right)$ per hour. Thus, the total labor hours and cost are $\mathrm{H}=\mathrm{H}_{1} \mu_{1}+\mathrm{H}_{2} \mu_{2}$ and $\mathrm{Lc}=\mathrm{Lc}_{1} \mu_{1}+\mathrm{Lc}_{2} \mu_{2}$. This indicates that the completion of this case will require overtime labor.

\subsection{Electrical Power Cost}

According to a report by Taiwan's Ministry of Economic Affairs (MOEA), the electrical power per $\mathrm{mt}$ of finished steel is about $0.55 \mathrm{KW}$. In this case, assume that the use of electrical power includes the batch level in Process 1 and the unit level in Processes 2 and 3 to calculate them. In Process 1, the raw material of steel-scrap in an EAF can contain $100 \mathrm{mts}$ (B) per batch and an electricity consumption and time of approximately $45 \mathrm{KW}\left(\mathrm{Dn}_{1}\right)$ and 0.75 hours. In Processes 2 and 3, one metric ton $(\mathrm{mt})$ of finished steel product for $\mathrm{P}_{2}$ or $\mathrm{P}_{3}$ takes an hour and about $0.1 \mathrm{KW}\left(\mathrm{Dn}_{2}\right.$ or $\left.\mathrm{Dn}_{3}\right)$. The electrical power cost of $1 \mathrm{KW}$ is USD85 (Du). As shown in Equation (1), Du*Dn $*\left(\sum_{\mathrm{j}=1}^{3} \mathrm{X}_{\mathrm{j}}\right)$ and $\mathrm{Du} *\left[\left(\mathrm{Dn}_{2} * \mathrm{Q}_{2}\right)\right.$ $\left.+\left(\mathrm{Dn}_{3} * \mathrm{Q}_{3}\right)\right]$ represent the total direct electricity power costs at the batch level in Process 1 and two unit-levels in Processes 2 and 3, respectively, as soon as posible.

\subsection{Machine Hours and Cost}

This steel manufacturing produces three different products $\mathrm{P}_{1}, \mathrm{P} \#_{2}$, and $\mathrm{P} \#_{3}$ by using different machines in different Processes, 1, 2, and 3, respectively. Firstly, in Process 1 for one batch, the normal working time of the operating machine is 1.25 hours, including 0.5 hours of setting up time and 0.75 hours of production time. Normally, the working days are $8(\mathrm{nh})$ hours each day and $22(\mathrm{nd})$ working days in a period, as shown in Equation (12), $\mathrm{Fh}_{1} \leqq 176(8 * 22)$. The total direct machine cost will be fixed at $\mathrm{F}_{1}=\mathrm{USD} 100,000$ for a period.

In this case, product $\mathrm{P \#}_{1}$ can be sold to customers or transferred to Processes 2 and 3 as semi-manufactured goods and be used to produce products $\mathrm{P \#}_{2}$ or $\mathrm{P}_{3}$. Both Processes 2 and 3 have 10 separate production lines that can produce different products independently. We assume that each unit of products $\mathrm{P}_{2}$ or $\mathrm{P}_{3}$ takes one hour of working process, but their machine costs in each process are fixed to $F_{2}=U S D 50,000$ and $F_{3}=U S D 150,000$, respectively, for a period. According to the previous Section 5.1., the $\mathrm{Q}_{2}$ and $\mathrm{Q}_{3}$ have to sell more than $3500 \mathrm{mts}$ individually each period; thus, $\mathrm{Fh}_{2}$ and $\mathrm{Fh}_{3}$ also separately require more than 3500 hours in Processes 2 and 3 in a period.

The terms from Equation (12) $\mathrm{Fh}_{2} \geqq 3500$ and $\mathrm{Fh}_{3} \geqq 3500$ are the constraints associated with the machine hours and are equal to the direct labor hours in Processes 2 and 3. The terms in the fifth set of 
parentheses in Equation (1), i.e., $\sum_{i=1}^{3} F_{i}=F_{1}+F_{2}+F_{3}=100,000+50,000+150,000=300,000$, represent the total direct machine cost.

\section{6. $\mathrm{CO}_{2}$ Emission Quantity and Cost}

In a period, the carbon footprint will be calculated based on the production batches in Process 1 and the quantity of 40 (cr) mts carbon footprint emissions each batch will make. Assume that the carbon tax rate is free $\left(r_{1}=0\right)$ when the total carbon emission quantity is less than $3000 \mathrm{mts}\left(\mathrm{eeq}_{1}\right)$; the carbon tax rate is $r_{2}$ (USD2/ each $\mathrm{mt}$ ) when the carbon emission quantity is between 3000 (eeq l $_{1}$ ) and 4000 (eeq $)$ mts; and the carbon tax rate is $\mathrm{r}_{3}$ (USD9 / each $\mathrm{mt}$ ) when the carbon emission quantity is between $4000\left(\mathrm{eeq}_{2}\right)$ and $7000\left(\mathrm{eeq}_{3}\right) \mathrm{mts}$. Thus, the total carbon footprint emission quantity and the carbon tax costs are eeq $=$ eeq $_{1^{*}} \gamma_{1}+$ eeq $_{2^{*}} \gamma_{2}+$ eeq $_{3^{*}} \gamma_{3}=3000 \gamma_{1}+4000 \gamma_{2}+7000 \gamma_{3}$ and eec $b=$ eec $_{1^{*}} \gamma_{1}$ $+\operatorname{eec}_{2} * \gamma_{2}+\operatorname{eec}_{3}^{*} \gamma_{3}=2000 \gamma_{2}+29,000 \gamma_{3}$, respectively. The constraints associated with the carbon tax cost are shown in Equations (13)-(20).

\subsection{Other Indirect Costs}

The various direct costs in this case are described above. However, the total operating costs also include various indirect costs, such as indirect material cost, indirect labor cost, commission fee, etc. Assume that the other indirect costs are estimated by using the percentage of a product's revenue $\left(\mathrm{pr}_{\mathrm{i}}\right)$, i.e., $3 \%, 5 \%$, and $5 \%$ for products $\mathrm{P \#}_{1}, \mathrm{P \#}_{2}$, and $\mathrm{P} \#_{3}$, respectively. The seventh term in Equation (1), i.e., $\sum_{\mathrm{i}=1}^{3} \mathrm{Oc}_{\mathrm{i}}=\sum_{\mathrm{i}=1}^{3} \mathrm{P}_{\mathrm{i}} \mathrm{Q}_{\mathrm{i}} * \mathrm{pr}_{\mathrm{i}}=\mathrm{Q}_{1} * \mathrm{P}_{1} * 3 \%+\mathrm{Q}_{2} * \mathrm{P}_{2} * 5 \%+\mathrm{Q}_{3} * \mathrm{P}_{3} * 5 \%$, represents the total other indirect costs.

\subsection{The Optimal Solution}

According to the model, Equations (1)-(20) and the descriptions of Sections 5.1-5.7, the mathematical programming model for the illustrative example data, as shown in Table 2 (called Case 1 in this paper), is presented in Table 3. The model of Case 1 is solved by the LINGO software, and its optimal solution is presented at the bottom of Table 3. The optimal product-mix in the sales quantity of the products $\left(P \#_{i}\right)$ are $\left(\mathrm{Q}_{1}, \mathrm{Q}_{2}, \mathrm{Q}_{3}\right)=(2002,3504,7105)$, and the optimal batch numbers of three kinds of steel-scrap recycled materials $M_{j}$ (including: $M_{1}$ lowest, $M_{2}$ middle, and $M_{3}$ highest levels) are $\left(\mathrm{X}_{1}, \mathrm{X}_{2}, \mathrm{X}_{3}\right)=(11,64,65)$. In addition, the company needs to use overtime direct labor hours (since $\eta_{2}=1$ ), and the carbon tax cost falls within the second taxable range of the carbon emission quantity (since $\gamma_{3}=1$ ).

In addition, the detailed information under the optimal solution is shown in Table 4. For example, from the sales point-of-view, the optimal product-mix for the sales quantity of three products (including $\left.\mathrm{Q}_{1}, \mathrm{Q}_{2}, \mathrm{Q}_{3}\right)=(2002,3504,7105)$ is subject to the following constraints: $2000 \leqq \mathrm{Q}_{1} \leqq 4000, \mathrm{Q}_{2} \geq 3500$, and $Q_{3} \geqq 3500$. Under this optimal solution, the quantity of the byproduct will be $Q_{p}=\sum_{j=1}^{3} X_{j}\left(B-R_{j}\right)$ $=\mathrm{X}_{1}\left(\mathrm{~B}-\mathrm{R}_{1}\right)+\mathrm{X}_{2}\left(\mathrm{~B}-\mathrm{R}_{2}\right)+\mathrm{X}_{3}\left(\mathrm{~B}-\mathrm{R}_{3}\right)=11 *(100-88)+64 *(100-91)+65 *(100-94)=1098$, since $\mathrm{X}_{1}=11$, $X_{2}=64$ and $X_{3}=65, B=100, R_{1}=88, R_{2}=91$, and $R_{2}=94$. Additionally, the optimal input quantity of $P \#_{1}$ for salling $P \#_{1}$ and producing $P \#_{2-3}$ is $Q_{i} / T_{i}$ to obtain $Q_{1}=2002, Q_{2}=3650$, and $Q_{3}=7250$, as shown in Table 4. 
Table 3. The mathematical programming model and optimal solution (Case1).

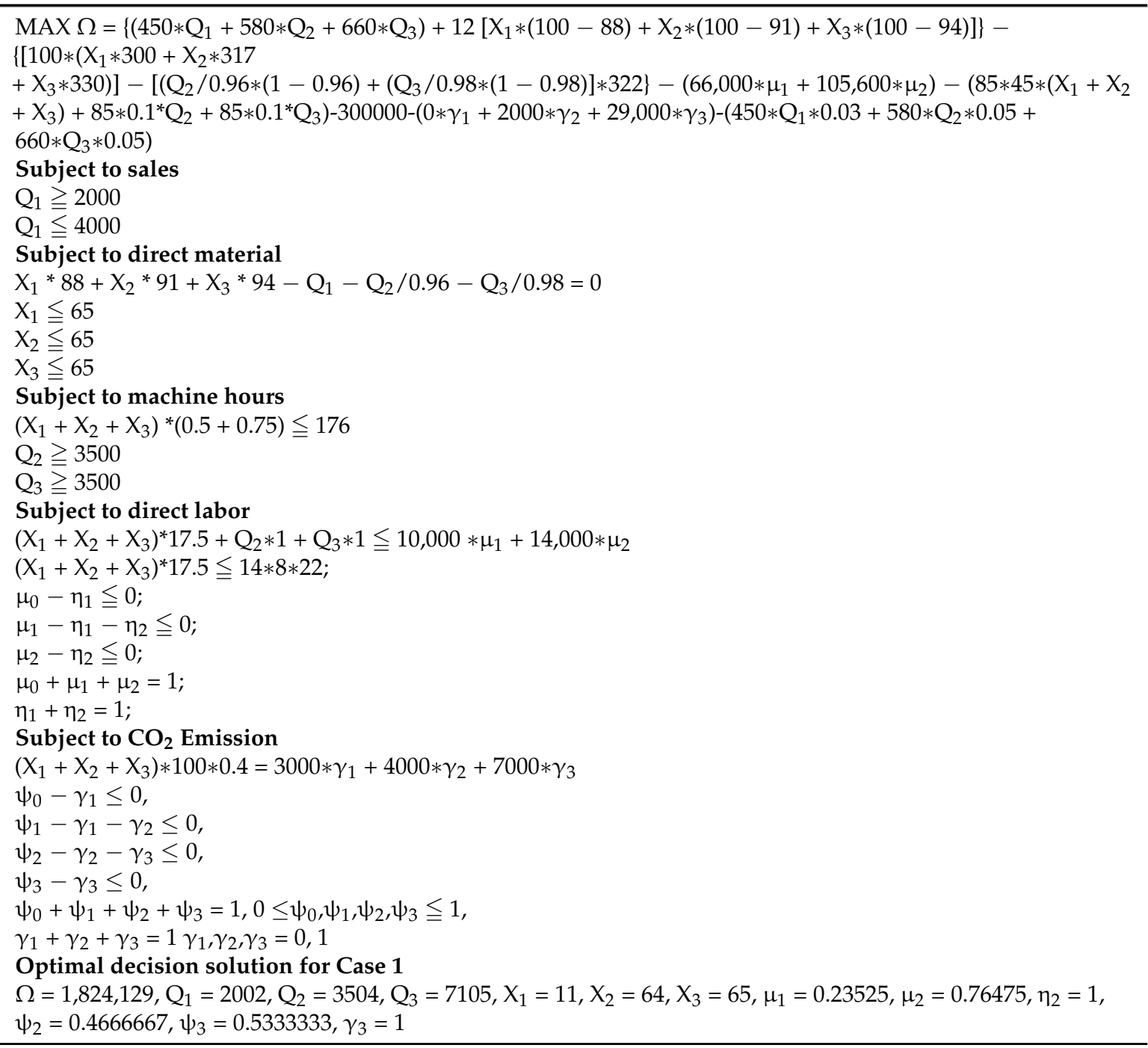


Table 4. The detailed data list of Case 1 (unit: mt/USD/hours).

\begin{tabular}{|c|c|c|c|c|c|c|}
\hline Description & \multicolumn{3}{|c|}{ Material $\left(\mathbf{M}_{\mathbf{j}}\right)$ for $\mathrm{P}_{1}$} & \multicolumn{3}{|c|}{ Products $\left(\mathbf{P} \#_{i}\right)$} \\
\hline Sales: & & & & $\mathrm{P}_{1}$ & $\mathrm{P \#}_{2}$ & $\mathrm{P \#}_{3}$ \\
\hline$\overline{\text { Maximum demand }\left(\mathrm{Q}_{\mathrm{i}}\right) / \mathrm{mt}}$ & & & & 2002 & 3504 & 7105 \\
\hline Byproduct $Q^{\prime}$ ty $\left(Q_{p}\right) / \mathrm{mt}^{1}$ & & & & 1098 & & \\
\hline Selling unit price-product/USD & & & & $\$ 450$ & $\$ 580$ & $\$ 660$ \\
\hline Selling unit price-byproduct/USD & & & & $\$ 12$ & & \\
\hline \multicolumn{7}{|l|}{ Direct material constraint: } \\
\hline \multicolumn{7}{|l|}{ Batch-level activity: } \\
\hline Direct material: & $\mathrm{M}_{1}$ & $\mathrm{M}_{2}$ & $\mathrm{M}_{3}$ & & & \\
\hline Cost/unit price/mt & $\$ 300$ & $\$ 317$ & $\$ 330$ & & & \\
\hline Input total batches (100 mts / 1 batch) & 11 & 64 & 65 & & & \\
\hline Output product $1\left(\mathrm{P \#}_{1}\right)$ : (mts / 1 batch) & 88 & 91 & 94 & & & \\
\hline $\mathrm{P \#}_{1}$ for the $\mathrm{P} \#_{\mathrm{i}} / \mathrm{mt}$ & & & & 1 & 0.96 & 0.98 \\
\hline Transfer $\mathrm{P \#}_{1}\left(\mathrm{q}_{\mathrm{i}}\right)$ to the ith process $/ \mathrm{mts}^{2}$ & & & & 2002 & 3650 & 7250 \\
\hline \multicolumn{7}{|l|}{$\begin{array}{l}\text { Recycling the byproduct }\left(\mathrm{M}_{2 \mathrm{r}}\right) \text { of } \\
\text { products } 2 \text { and } 3 / \mathrm{mt}^{3}\end{array}$} \\
\hline Direct labor constraint & & & & 0 & 146 & 145 \\
\hline \multicolumn{7}{|l|}{$\overline{\text { Labor cost }\left(\mathrm{P} \#_{1} / \mathrm{P} \#_{2} / \mathrm{P} \#_{3}\right)^{4}}$} \\
\hline Labor hours (P\#1/P\#2/P\#3) 5 & & & & $\$ 16,170$ & $\$ 26,539$ & $\$ 53,575.1$ \\
\hline Electrical power cost & & & & 2450 & 3504 & 7105 \\
\hline Batch-level cost ${ }^{6}$ & & & & $\$ 535,500$ & & \\
\hline Unit-level cost ${ }^{6}$ & & & & & $\$ 29,784$ & $\$ 60,393$ \\
\hline \multicolumn{7}{|l|}{ Direct machine constraint } \\
\hline Machine cost & & & & $\$ 100,000$ & $\$ 50,000$ & $\$ 150,000$ \\
\hline Machine hours (batch/unit) & & & & 175 & 3504 & 7105 \\
\hline \multicolumn{7}{|l|}{$\mathrm{CO}_{2}$ emission constraint } \\
\hline Batch-level mts ${ }^{7}$ & & & & 5600 & & \\
\hline Batch-level cost ${ }^{8}$ & & & & $\$ 16,400$ & & \\
\hline Other indirect cost ${ }^{9}$ & & & & $\$ 27,027$ & $\$ 101,616$ & $\$ 234,465$ \\
\hline
\end{tabular}

Note: ${ }^{1}$ Byproduct $\mathrm{Q}^{\prime} \mathrm{ty}=1098\left(\mathrm{Q}_{\mathrm{p}}=\sum_{\mathrm{j}=1}^{3} \mathrm{X}_{\mathrm{j}}\left(\mathrm{B}-\mathrm{R}_{\mathrm{j}}\right) ;{ }^{2}\right.$ Transfer $\mathrm{P}_{1}\left(\mathrm{q}_{\mathrm{i}}\right)=\left(\mathrm{Q}_{\mathrm{i}} / \mathrm{T}_{\mathrm{i}}\right) ;{ }^{3}$ Recycling the byproduct $\left(\mathrm{M}_{2 \mathrm{r}}\right)$

$=\left(\mathrm{q}_{\mathrm{i}}-\mathrm{Q}_{\mathrm{i}}\right) ;{ }^{4}$ Labor cost $\left(\mathrm{P}_{1} / \mathrm{P}_{2-3}\right)(\mu 1=0.23525, \mu 2=0.76475)=\$ 66000^{*} 0.23525+\$ 105600^{*} 0.76475=\$ 96284.1$ $=\mathrm{P} \#_{1}(\$ 16,170)+\mathrm{P} \#_{2}(\$ 26,539)+\mathrm{P} \#_{3}(\$ 53,575.1) ;{ }^{5}$ Labor hours $\left(\mu_{1}=0.23525, \mu_{2}=0.76475\right)=10000 \mathrm{H}^{*} 0.23525+$ $14000 \mathrm{H}^{*} 0.76475=13059 \mathrm{H}=\mathrm{P} \#_{1}(2450 \mathrm{H})+\mathrm{P} \#_{2}(3504 \mathrm{H})+\mathrm{P} \#_{3}(7105 \mathrm{H}) ;{ }^{6}$ Electrical power cost $=\left(85^{*} 45^{*}\left(\mathrm{X}_{1}+\mathrm{X}_{2}+\mathrm{X}_{3}\right)\right.$ $\left.+85^{*} 0.1^{*} \mathrm{Q}_{2}+85^{*} 0.1^{*} \mathrm{Q}_{3}\right)=\mathrm{P} \#_{1}(\$ 535,500)+\mathrm{P} \#_{2}(\$ 29,784)+\mathrm{P} \#_{3}(\$ 60,393) ;{ }^{7} \mathrm{CO}_{2}$ emission quantity $\left(\psi_{2}=0.4666667, \psi_{3}\right.$ $=0.5333333)=3000^{*} \psi_{1}+4000^{*} \psi_{2}+7000^{*} \psi_{3}=5600 ;{ }^{8} \mathrm{CO}_{2}$ emission cost $\left(\psi_{2}=0.4666667, \psi_{3}=0.5333333\right)=0^{*} \psi_{1}+$ $2000^{*} \Psi_{2}+29,000^{*} \Psi_{3}=\$ 16,400 ;{ }^{9}$ Other indirect cost $=450^{*} \mathrm{Q}_{1}{ }^{*} 0.03+580^{*} \mathrm{Q}_{2}{ }^{*} 0.05+660^{*} \mathrm{Q}_{3}{ }^{*} 0.05=\mathrm{P} \#_{1}(\$ 27,027)+$ $\mathrm{P \#}_{2}(\$ 101,616)+\mathrm{P \#}_{3}(\$ 234,465)$.

\section{Three Cases on Enhancing the Quality of Steel-Scrap}

This section explores two topics: one is the purchase of high cost steel-scrap and the other is for increasing the yield of $\mathrm{P \#}_{1}$ in the steelmaking process. Assume that the company can produce more quantity of $\mathrm{P \#}_{1}$ and reduce the quantity of byproducts in Process 1; if suppliers are requested to conduct more services, meaning to clean, cut, crush, or classify for improving the quality of steel-scrap, then, enhancing the quality of steel-scrap not only increases the productivity of $\mathrm{P}_{1}$ but also increases the business profit.

We will discuss an additional 3 cases, from Case 2 to Case 4, which focus only on the purchase of three different levels of steel purity of steel-scrap, where the illustrative data in Case 1 is unchanged. According to Section 5.2.1, there are three levels of steel purity $\left(\mathrm{M}_{\mathrm{j}}\right): \mathrm{M}_{1}$ lowest $\left(\mathrm{Mc}_{1}=\mathrm{USD} 300\right), \mathrm{M}_{2}$ middle $\left(\mathrm{Mc}_{2}=\mathrm{USD}\right.$ 317), and $\mathrm{M}_{3}$ highest $\left(\mathrm{Mc}_{3}=\mathrm{USD}\right.$ 330). In Case 2 to Case 4 , assume that the cost of steel-scrap will gradually increase the purchase cost of USD 8 per $\mathrm{mt}$ to arrive at $\mathrm{Mc}_{\mathrm{j}}{ }^{\prime}$ (including $\mathrm{Mc}_{1}{ }^{\prime}=$ USD 308, $\mathrm{Mc}_{2}{ }^{\prime}=$ USD 325, and $\mathrm{Mc}_{3}{ }^{\prime}=$ USD 338) in order to increase the P\#1 yield of $2 \mathrm{mt}$ per batch. Table 5 shows the gradual change in the steel purity levels of steel-scraps from Case 1 to Case 4. The purchasing costs from $\mathrm{Mc}_{\mathrm{j}}$ (including: $\mathrm{Mc}_{1}, \mathrm{Mc}_{2}, \mathrm{Mc}_{3}$ ) to $\mathrm{Mc}_{\mathrm{j}}{ }^{\prime}$ (including: $\mathrm{Mc}_{1}{ }^{\prime}, \mathrm{Mc}_{2}{ }^{\prime}, \mathrm{Mc}_{3}{ }^{\prime}$ ) are gradually higher, which will also increase the quantity of $P \#_{1}$ from $R_{j}$ (including: $R_{1}, R_{2}, R_{3}$ ) to $R_{j}{ }^{\prime}$ 
(including: $\mathrm{R}_{1}{ }^{\prime}, \mathrm{R}_{2}{ }^{\prime}, \mathrm{R}_{3}{ }^{\prime}$ ). For example, from Case 1 to Case 2 , due to the higher quality, the purchase unit cost of steel-scrap increased from USD300 (Mc1 $)$ to USD308 $\left(\mathrm{Mc}_{1}{ }^{\prime}\right)$, and the output quantity of P\# increased from $R_{1}(88)$ to $R_{1}{ }^{\prime}(90)$ each batch.

Table 5. Cases 1-4 for changes in the unit costs of steel-scrap and the output of $\mathrm{P}_{1}$ *.

\begin{tabular}{|c|c|c|c|c|c|c|}
\hline & \multicolumn{3}{|c|}{$\mathbf{M c}_{\mathrm{j}}$} & \multicolumn{3}{|c|}{$M c_{j}^{\prime}=M c_{j}+$ USD 8} \\
\hline & $\begin{array}{c}\mathrm{Mc}_{1} \\
@ 300\end{array}$ & $\begin{array}{l}\mathrm{Mc}_{2} \\
@ 317\end{array}$ & $\begin{array}{c}\mathrm{Mc}_{3} \\
@ 330\end{array}$ & $\begin{array}{l}\mathrm{Mc}_{1}{ }^{\prime} \\
@ 308\end{array}$ & $\begin{array}{l}\mathrm{Mc}_{2}{ }^{\prime} \\
@ 325\end{array}$ & $\begin{array}{l}\mathrm{Mc}_{3}{ }^{\prime} \\
@ 338\end{array}$ \\
\hline & \multicolumn{6}{|c|}{$\mathrm{P} \#_{1} /$ Batch (100 mts) } \\
\hline & \multicolumn{3}{|c|}{$R_{j}$} & \multicolumn{3}{|c|}{$R_{j}^{\prime}=R_{j}+2 m t s$} \\
\hline & $\mathrm{R}_{1}$ & $\mathrm{R}_{2}$ & $\mathrm{R}_{3}$ & $\mathrm{R}_{1}^{\prime}$ & $\mathrm{R}_{2}^{\prime}$ & $\mathrm{R}_{3}^{\prime}$ \\
\hline & 88 & 91 & 94 & 90 & 93 & 96 \\
\hline Case 1 & 300 & 317 & 330 & & & \\
\hline Case 2 & & 317 & 330 & 308 & & \\
\hline Case 3 & & & 330 & 308 & 325 & \\
\hline Case 4 & & & & 308 & 325 & 338 \\
\hline
\end{tabular}

* Changes in the purchasing cost of steel-scrap from $\mathrm{Mc}_{\mathrm{j}}$ to $\mathrm{Mc}_{\mathrm{j}}{ }^{\prime}$ and in the output of $\mathrm{P} \#_{1}$ from $\mathrm{R}_{\mathrm{j}}$ to $\mathrm{R}_{\mathrm{j}}{ }^{\prime}$ each batch from Case 1 to Case 4.

\subsection{Optimal Solution for Cases 1-4}

Cases 1-4 are solved by using the LINGO software, and the optimal solutions are shown in Table 6. The first column shows a gradual increase in $\Omega$ from Case 1 to Case 4 . In comparing Case 1 with Case 2 , we find that the only difference in the $Q_{3}$ column of Sales quantity are 7105 in Case 1 and 7056 in Case 2, but the profit of Case $2(\Omega=1,874,986)$ is higher than that of Case $1(\Omega=1,824,129)$. The reason is that the input material in Case 2 is adapted at the lowest material cost of $\mathrm{Mc}_{1}{ }^{\prime}$ (USD308) and the number of batches arriving at 65 is more than the other Cases.

Table 6. The optimal solutions for Cases 1-4.

\begin{tabular}{|c|c|c|c|c|c|c|c|c|c|c|c|c|c|}
\hline \multirow{2}{*}{ Case } & \multirow{2}{*}{$\begin{array}{c}\text { Profit } \\
\Omega\end{array}$} & \multicolumn{3}{|c|}{ Sales quantity } & \multicolumn{3}{|c|}{ Batches $X_{j}$} & \multicolumn{2}{|c|}{ Direct Labor $\mu_{\mathrm{w}}$} & \multicolumn{2}{|c|}{$\mathrm{CO}_{2}$ emission $\psi_{\mathrm{e}}$} & \multirow[b]{2}{*}{$\gamma_{3}$} & \multirow[b]{2}{*}{$\eta_{2}$} \\
\hline & & $\mathrm{Q}_{1}$ & $\mathbf{Q}_{2}$ & $\mathrm{Q}_{3}$ & $X_{1}$ & $X_{2}$ & $x_{3}$ & $\mu_{1}$ & $\mu_{2}$ & $\psi_{2}$ & $\psi_{3}$ & & \\
\hline 1 & $1,824,129$ & 2002 & 3504 & 7105 & 11 & 64 & 65 & 0.23525 & 0.76475 & 0.466667 & 0.533333 & 1 & 1 \\
\hline 2 & $1,874,986$ & 2002 & 3504 & 7056 & 65 & 16 & 59 & 0.24750 & 0.75250 & 0.466667 & 0.533333 & 1 & 1 \\
\hline 3 & $1,885,635$ & 2001 & 3504 & 7252 & 11 & 65 & 64 & 0.19850 & 0.80150 & 0.466667 & 0.533333 & 1 & 1 \\
\hline 4 & $1,909,646$ & 2002 & 3504 & 7350 & 21 & 54 & 65 & 0.17400 & 0.82600 & 0.466667 & 0.533333 & 1 & 1 \\
\hline
\end{tabular}

\subsection{Further Analysis}

The detailed information of the optimal solutions of Cases 1-4 is shown in Table 7. Columns 1-3 show the unit costs of the various purity levels of steel-scrap, including from Case $1\left(\mathrm{Mc}_{1}=300\right.$, $\mathrm{Mc}_{2}=317$, and $\left.\mathrm{Mc}_{3}=330\right)$ to Case $4\left(\mathrm{Mc}_{1}{ }^{\prime}=308, \mathrm{Mc}_{2}{ }^{\prime}=325\right.$, and $\left.\mathrm{Mc}_{3}{ }^{\prime}=338\right)$, as shown in Table 5 . Column 4 shows $\mathrm{M}_{2 \mathrm{r}}$, the quantity of steel-scrap byproduct from Process 2 or Process 3 in Cases 1-4; column 5 shows the quantity of byproduct $Q_{p}=\sum_{j=1}^{3} X_{j}\left(B-R_{j}\right)$, for example, $Q_{p}$ of Case $1=1098$, as shown in Table 4. Columns $6\left(\mathrm{P}_{\mathrm{i}}^{*}{ }^{*} \mathrm{Q}_{\mathrm{i}}\right)$ and $7\left(\mathrm{~K}_{1}{ }^{*} \mathrm{Q}_{\mathrm{p}}\right)$ show the sales amounts of three products and the byproducts, respectively, where $P_{1}=\$ 450, P_{2}=\$ 580$, and $P_{3}=\$ 660 ; Q_{1}, Q_{2}$, and $Q_{3}$ are as shown in Table 6; and $\mathrm{K}_{1}=\mathrm{USD} 12$. Columns $8\left(\mathrm{Mc}_{\mathrm{j}}{ }^{*} \mathrm{X}_{\mathrm{j}}{ }^{*} \mathrm{~B}\right)$ and $9\left(\mathrm{M}_{2 \mathrm{r}}{ }^{*} \mathrm{Mc}_{2 \mathrm{r}}\right)$ show the costs of purchasing materials and recycling the byproducts, where $\mathrm{B}=100$ as discussed in Section 5.1. and $\mathrm{Mc}_{2 \mathrm{r}}=322$ as discussed in Section 5.2.1. Furthermore, Column 10 shows the labor cost (Lc); columns 11 and 12 show the electrical power cost $\left(\mathrm{Dc}_{\mathrm{i}}\right)$ and carbon emission cost $\left(\mathrm{eec}_{\mathrm{b}}\right)$, and column 13 shows the other indirect costs $\left(\mathrm{Oc}_{\mathrm{i}}\right)$. Table 8 shows the sales, various costs, and total profit for four cases based on the data of Tables 6 and 7. 
Table 7. More in-depth information for the optimal solutions (Unit: USD/mt).

\begin{tabular}{|c|c|c|c|c|c|c|c|c|c|c|c|c|c|}
\hline \multirow{3}{*}{ Case } & \multicolumn{3}{|c|}{$\begin{array}{c}\text { Assumptions } \\
\text { Mcj } \rightarrow \text { Mcj' (USD) }\end{array}$} & \multicolumn{2}{|c|}{$\begin{array}{l}\text { Quantity } \\
\text { (mt) }\end{array}$} & \multicolumn{2}{|c|}{$\begin{array}{l}\text { Sales Amount } \\
\text { (USD) }\end{array}$} & \multicolumn{2}{|c|}{ Material Cost (USD) } & \multicolumn{4}{|c|}{ Costs (USD) } \\
\hline & (1) & (2) & (3) & (4) & (5) & (6) & (7) & (8) & (9) & (10) & (11) & (12) & (13) \\
\hline & $\mathbf{M c}_{1}$ & $\mathbf{M c}_{2}$ & $\mathbf{M c}_{3}$ & $\mathbf{M}_{2 \mathbf{r}}$ & $\mathrm{Q}_{\mathrm{p}}$ & $\mathbf{P}_{\mathrm{i}}^{*} \mathbf{Q}_{\mathrm{i}}$ & $K_{1}{ }^{*} Q_{p}$ & $M c_{j}^{*} X_{j}^{*} B$ & $\mathbf{M}_{2 \mathrm{r}}{ }^{*} \mathbf{M} c_{2 \mathrm{r}}$ & Lc & $D c_{i}$ & $\mathbf{e e c}_{\mathrm{b}}$ & $\mathrm{Oc}_{\mathrm{i}}$ \\
\hline 1 & 300 & 317 & 330 & 291 & 1098 & $7,622,520$ & 13,176 & $4,503,800$ & 93,702 & 96,284 & 625,677 & 16,400 & 363,108 \\
\hline 2 & 308 & 317 & 330 & 290 & 1148 & $7,590,180$ & 13,776 & $4,456,200$ & 93,380 & 95,799 & 625,260 & 16,400 & 361,491 \\
\hline 3 & 308 & 325 & 330 & 294 & 949 & $7,719,090$ & 11,388 & $4,563,300$ & 94,668 & 97,739 & 626,926 & 16,400 & 367,946 \\
\hline 4 & 308 & 325 & 338 & 296 & 848 & $7,784,220$ & 10,176 & $4,598,800$ & 95,312 & 98,710 & 627,759 & 16,400 & 371,193 \\
\hline
\end{tabular}

Table 8. Sales, costs, and total profit of Cases 1-4 (Unit: USD).

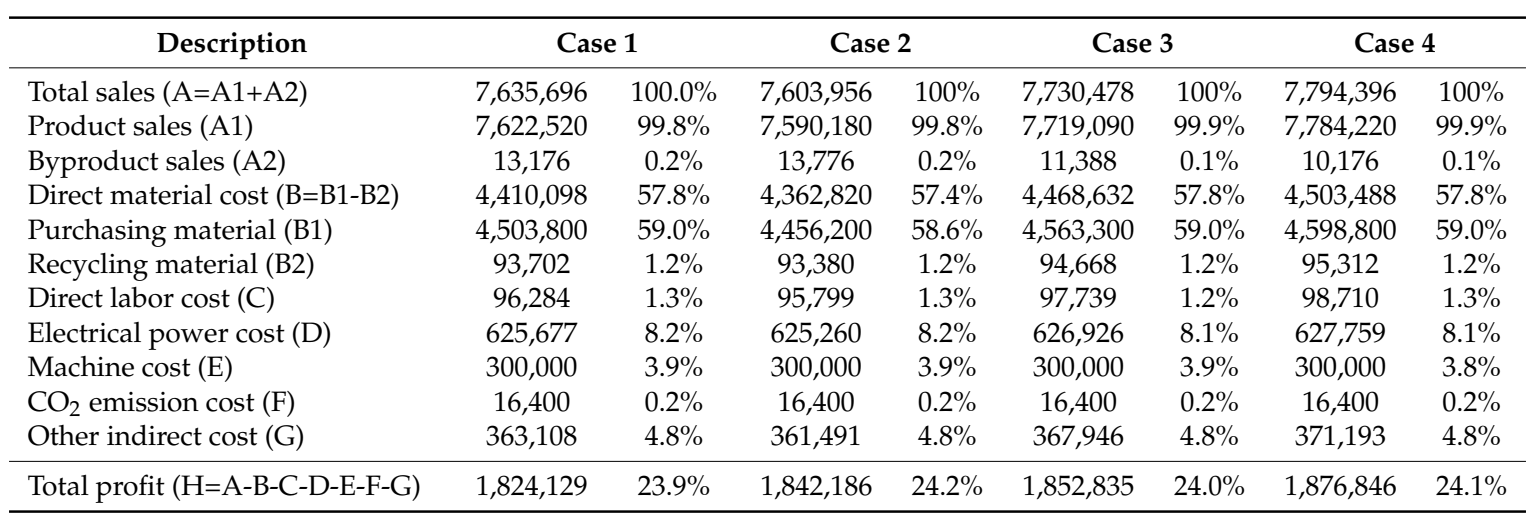

\section{Summary and Conclusions}

ABC (Activity-Based Costing) implementation can satisfy the cost information needs of company managers. However, ABSC (Activity-Based Standard Costing) may be a suitable costing tool to enhance the business operating abilities of quality, cost, delivery, service, resources, and productivity in a modern smart factory that uses high-tech unmanned vehicles, advanced robots, various sensors, etc.

In the analysis of Cases 1-4, we hypothesized that (1) three levels of steel purity steel-scrap can produce product $\mathrm{P}_{1}$ steel billets and byproduct slag $S_{1}$ and (2) in the purchasing process, each level of recycled steel-scrap can gradually enhance its steel purity quality, which not only increases the yield of $\mathrm{P \#}_{1}$ products but also reduces the quantity of byproduct $\mathrm{S}_{1}$. With some limited resources, the optimal solution and optimal profit are obtained from the mathematical program decision model and solved using the LINGO software, as shown in Tables 2-8. The final profit, as shown in the last row of Table 8, gradually increased from Case 1 to Case 4. Affirmatively, ABSC may be used soon in the digital era. The high-tech manufacturing of EAF adapts the recycled material of steel-scrap for reproducing various new steel products, which will make great global contributions in terms of pollution and nature mineral resources.

Finally, ABSC can be used to integrate internal and external systems in MES to connect all real-time information regarding the relevant requirements that will help all industries in the digital age.

Author Contributions: W.-H.T. provided the research idea and the research purpose and designed the research; S.-H.L. provided the research method, collected and analyzed the data, and wrote the paper; C.-T.H. provided the research method and analyzed the data; W.-H.T. provided the research method and supervised, corrected, and revised this paper. All authors read and approved the final manuscript.

Funding: This research was funded by the Ministry of Science and Technology of Taiwan under Grant No. MOST106-2410-H-008-020-MY3.

Acknowledgments: The authors are extremely grateful to the sustainability journal editorial team and reviewers who provided valuable comments for improving the quality of this article. The authors also would like to thank the Ministry of Science and Technology of Taiwan for the financial support of this research under Grant No. MOST106-2410-H-008-020-MY3.

Conflicts of Interest: The authors declare no conflict of interest. 


\section{References}

1. Qin, J.; Liu, Y.; Grosvenor, R. A Categorical Framework of Manufacturing for Industry 4.0 and Beyond. Procedia CIRP 2016, 52, 173-178. [CrossRef]

2. Kletti, J. Manufacturing Execution System-MES; Springer: Berlin/Heidelberg, Germany; New York, NY, USA, 2007; pp. 61-78.

3. Tsai, W.-H.; Yang, C.-H.; Chang, J.-C.; Lee, H.-L. An-Activity-Based Costing Decision Model for Life Cycle Assessment in Green Building Projects. Eur. J. Oper. Res. 2014, 238, 607-619. [CrossRef]

4. Wikipedia. Steelmaking. Available online: https://en.m.wikipedia.org/wiki/Steelmaking (accessed on 23 January 2019).

5. American Iron and Steel Institute. Steel Production, Recycling. Available online: http://www.steel.org/ about-aisi/industry-profile.aspx (accessed on 23 January 2019).

6. Tsai, W.-H. Activity-Based Costing Model for Joint Products. Comput. Ind. Eng. 1996, 31, 725-729. [CrossRef]

7. Tsai, W.-H. Project Management Accounting Using Activity-Based Costing Approach. In The Handbook of Technology Management; Bidgoli, H., Ed.; John Wiley \& Sons, Inc.: Hoboken, NJ, USA, 2010; Volume 1, pp. 469-488.

8. Tsai, W.-H. A technical note on using work sampling to estimate the effort on activities under activity-based costing. Int. J. Prod. Econ. 1996, 43, 11-16. [CrossRef]

9. Wagner, T.; Herrmann, C.; Thiede, S. Industry 4.0 impacts on lean production systems. Procedia CIRP 2017, 63, 125-131. [CrossRef]

10. Bedolla, J.S.; D'Antonio, G.; Chiabert, P. A novel approach for teching IT tools with Lerning Factories. Procedia Manuf. 2017, 7, 175-181. [CrossRef]

11. Liu, C.; Xu, X. Cyber-Physical Machine Tool-The Era of Machine Tool 4.0. Procedia CIRP 2017, 63, 70-75. [CrossRef]

12. Pacaux-Lemoine, M.P.; Trentesaux, D.; Rey, G.Z.; Millot, P. Designing intelligent manufacturing systems through Human-Machine Cooperation principles: A human-centered approach. Comput. Ind. Eng. 2017, 111, 581-595. [CrossRef]

13. Gašová, M.; Gašo, M.; Štefánik, A. Advanced industrial tools of ergonomics based on Industry 4.0. Procedia Eng. 2017, 192, 219-224. [CrossRef]

14. Santos, M.Y.; e Sá, J.O.; Andrade, C.; Lima, F.V.; Costa, E.; Costa, C.; Martinho, B.; Galvão, J. A Big Data system supporting Bosch Braga Industry 4.0 strategy. Int. J. Inf. Manag. 2017, 36, 750-760. [CrossRef]

15. Moutaz, H.; Ahmed, E. The Readiness of ERP Systems for the Factory of the Future. Procedia Comput. Sci. 2015, 64, 721-728.

16. Grundstein, S.; Freitag, M.; Scholz-Reiter, B. A new method for autonomous control of complex job shopsIntegrating order release, sequencing and capacity control to meet due dates. J. Manuf. Syst. 2017, 42, 11-28. [CrossRef]

17. Kans, M.; Ingwald, A. Business Model Development towards Service Management 4.0. Procedia CIRP 2016, 47, 489-494. [CrossRef]

18. Wang, S.; Wan, J.; Zhang, D.; Li, D.; Zhang, C. Towards smart factory for industry 4.0: A self-organized multi-agent system with big data based feedback and coordination. Comput. Netw. Volume 2016, 101, 158-168. [CrossRef]

19. Stock, T.; Seliger, G. Opportunities of Sustainable Manufacturing in Industry 4.0. Procedia CIRP 2016, 40, 536-541. [CrossRef]

20. Becker, T.; Stern, H. Future trends in human work area design for cyber-physical production system. Procedia CIRP 2016, 57, 404-409. [CrossRef]

21. Wikipedia. Paris Agreement. Available online: https://en.wikipedia.org/wiki/parisagreement (accessed on 15 March 2018).

22. Tung Ho Steel Enterprise Corp. Profile, CSR, Products. Available online: http://www.tunghosteel.com/ EN/HomeEg/about/intro (accessed on 23 January 2019).

23. Tsai, W.-H.; Lin, S.-J.; Liu, J.-Y.; Lin, W.-R.; Lee, K.-C. Incorporating life cycle assessments into building project decision-making: An energy consumption and $\mathrm{CO}_{2}$ emission perspective. Energy 2011, 36, 3022-3029. [CrossRef] 
24. Bauerdick, C.J.; Helfert, M.; Menz, B.; Abele, E. A common sofrware Framework for Energy Data Based Monitoring and Controlling for Machine power Peak Reduction and Workpiece Quality Improvements. Procedia CIRP 2017, 61, 359-364. [CrossRef]

25. Chen, J.-Y.; Tai, K.-C.; Chen, G.-C. Application of programmable Logic Controller to Build-up an Intelligent Industry 4.0 Platform. Procedia CIRP 2017, 63, 150-155. [CrossRef]

26. Rudolph, J.P.; Emmelmann, C. A Cloud-Based Platform for Automted Order Processing in Additive Manufacturing. Procedia CIRP 2017, 63, 412-417. [CrossRef]

27. Chen, K.-C.; Lien, S.-Y. Machine-to-machine communications: Technologies and challenges. Ad Hoc Netw. 2014, 18, 3-23. [CrossRef]

28. Tsai, W.-H.; Lin, T.-W.; Chou, W.-C. Integrating Activity-Based Costing and Environmental Cost Accounting Systems: A Case Study. Int. J. Bus. Syst. Res. 2010, 4, 186-208. [CrossRef]

29. Tsai, W.-H.; Lin, T.W. A Mathematical Programming Approach to Analyze the Activity-Based Costing Product-Mix Decision with Capacity Expansions. In Applicatios of Management Science; Lawrence, K.D., Ed.; JAI Press Inc.: Greenwich, CT, USA, 2004; Volume 11, pp. 161-176.

30. Chinnathai, M.K.; Günther, T.; Ahmad, M.; Stocker, C.; Richter, L.; Schreiner, D.; Vera, D.; Reinhart, G.; Harrison, R. An application of physical flexibility and software reconfigurability for the automation of battery module assembly. Procedia CIRP 2017, 63, 604-609. [CrossRef]

31. de Sampaio, R.J.; Wollmann, R.R.; Vieira, P.F. A flexible production planning for rolling-horizons. Int. J. Product. Econ. 2017, 190, 31-36. [CrossRef]

32. de Man, J.C.; Strandhagen, J.O. An Industry 4.0 research agenda for sustainable business models. Procedia CIRP 2017, 63, 721-726. [CrossRef]

33. Poonpakdee, P.; Koiwanit, J.; Yuangyai, C. Decentralized Network Building Change in Large Manufacturing Companyies towards Industry 4.0. Procendia Comput. Sci. 2017, 110, 46-53. [CrossRef]

34. Meissner, H.; Ilsen, R.; Aurich, J.C. Analysis of control architectures in the context of Industry 4.0. Procedia CIRP 2017, 62, 165-169. [CrossRef]

35. Kolsch, P.; Herder, C.F.; Zimmermann, V.; Aurich, J.C. A novel concept for the development of availabilityoriented business models. Procedial CIRP 2017, 64, 340-344. [CrossRef]

36. Schlegel, A.; Langer, T.; Putz, M. Developing and harnessing the potential of SMEs for eco-efficient flexible production. Procedia Manuf. 2017, 9, 41-48. [CrossRef]

37. Majstorovic, V.; Stojadinovic, S.; Zivkovic, S.; Djurdjanovic, D.; Jakovljevic, Z.; Gligorijevic, N. Cyber-Physical Manufacturing Metrology Model (CPM) for sculptured surfaces- Turbine Blade Application. Procedia CIRP 2017, 63, 658-663. [CrossRef]

38. Lee, J.; Bagheri, B.; Kao, H.A. A Cyber-Physical Systems architecture for Industry 4.0-based manufacturing systems. Manuf. Lett. 2015, 3, 18-23. [CrossRef]

39. Li, H.; Parlikad, A.K. Social Internet of Industrial Things for Industrial and Manufacturing Assets. IFAC 2016, 49, 208-213.

40. Functional SAP ERP Modules. SAP ERP Modules: Complete List of SAP ERP Modules. Available online: https:/ / solutiondots.com/blog/sap-erp-modules/ (accessed on 13 January 2019).

41. Tsai, W.-H.; Yang, C.-H.; Huang, C.-T.; Wu, Y.-Y. The Impact of the Carbon Tax Policy on Green Building Strategy. J. Environ. Plan. Manag. 2017, 60, 1412-1438. [CrossRef]

42. Tsai, W.-H.; Tsaur, T.-S.; Chou, Y.-W.; Liu, J.-Y.; Hsu, J.-L.; Hsieh, C.-L. Integrating the Activity-Based Costing System and Life-Cycle Assessment into Green Decision Making. Int. J. Prod. Res. 2015, 53, 451-465. [CrossRef]

43. Tsai, W.-H.; Chang, J.-C.; Hsieh, C.-L.; Tsaur, T.-S.; Wang, C.-W. Sustainability Concept in Decision-Making: Carbon Tax Consideration for Joint Product Mix Decision. Sustainability 2016, 8, 1232. [CrossRef]

44. Tsai, W.-H. A Green Quality Management Decision Model with Carbon Tax and Capacity Expansion under Activity-Based Costing (ABC)—A Case Study in the Tire Manufacturing Industry. Energies 2018, 11, 1858. [CrossRef]

45. Tsai, W.-H. Carbon Taxes and Carbon Rights Cost Analysis for the Tire Industry. Energies 2018, 11, 2121. [CrossRef]

46. Tsai, W.-H.; Lu, Y.-H. A Framework of Production Planning and Control with Carbon Tax under Industry 4.0. Sustainability 2018, 10, 3221. [CrossRef] 
47. Tsai, W.-H. Green Production Planning and Control for the Textile Industry by Using Mathematical Programming and Industry 4.0 Techniques. Energies 2018, 11, 2072. [CrossRef]

48. Tsai, W.-H.; Jhong, S.-Y. Carbon Emission Cost Analysis with Activity-Based Costing. Sustainability 2018, 10, 2872. [CrossRef]

49. Tsai, W.-H.; Jhong, S.-Y. Production Decision Model with Carbon Tax for the Knitted Footwear Industry under Activity-Based Costing. J. Clean. Prod. 2019, 207, 1150-1162. [CrossRef]

50. Tsai, W.-H.; Lai, S.-Y. Green Production Planning and Control Model with ABC under Industry 4.0 for the Paper Industry. Sustainability 2018, 10, 2932. [CrossRef]

51. Tsai, W.-H.; Chu, P.-Y.; Lee, H.-L. Green Activity-Based Costing Production Planning and Scenario Analysis for the Aluminum-Alloy Wheel Industry under Industry 4.0. Sustainability 2019, 11, 756. [CrossRef]

2019 by the authors. Licensee MDPI, Basel, Switzerland. This article is an open access article distributed under the terms and conditions of the Creative Commons Attribution (CC BY) license (http:/ / creativecommons.org/licenses/by/4.0/). 